Prepared in cooperation with the U.S. Fish and Wildlife Service and U.S. Air Force

\title{
Assessment of Bird Exposure to Lead at Tyndall and Beale Air Force Bases, 2016-17
}

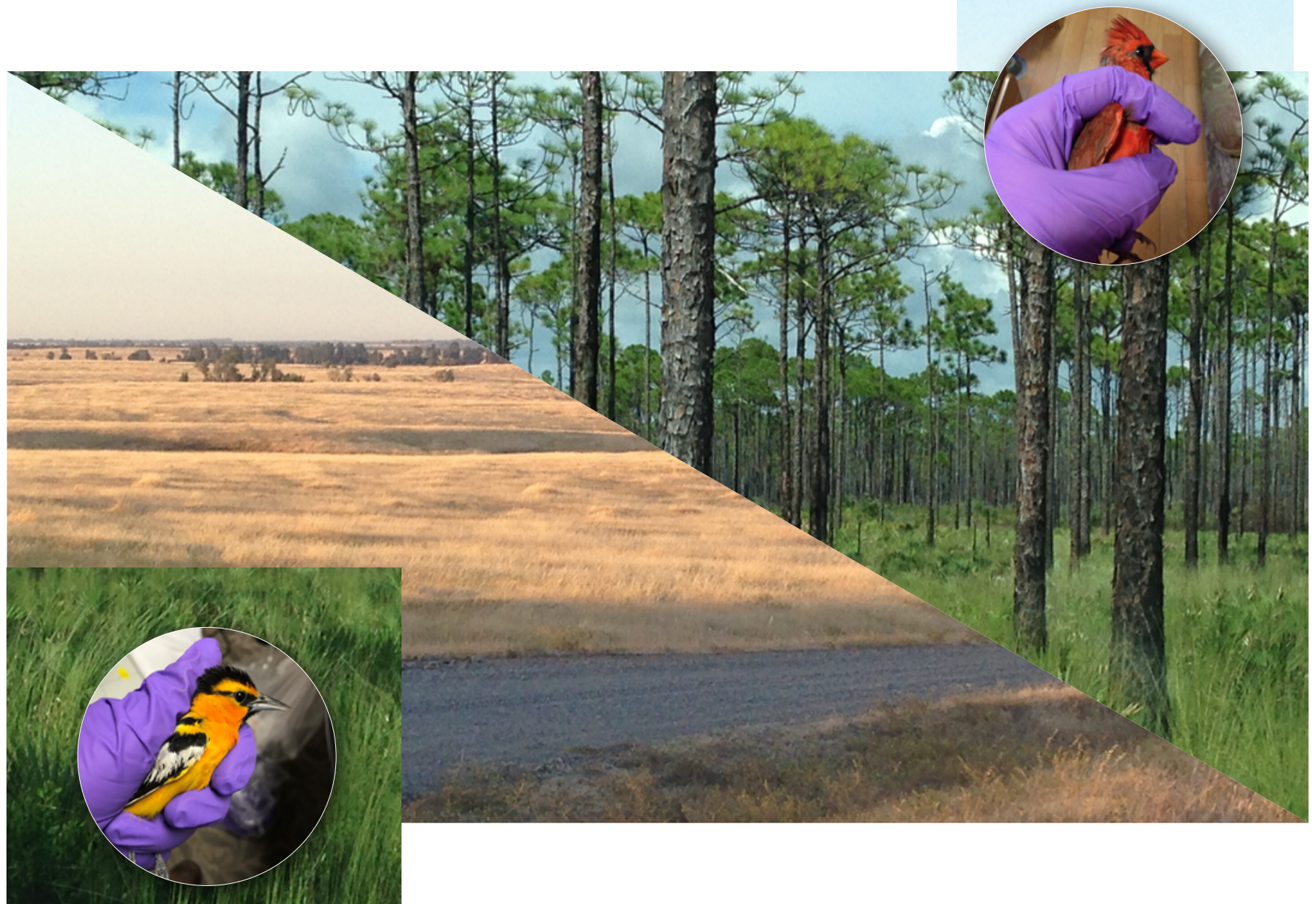

Scientific Investigations Report 2018-5164 
Cover. Photos of the St. Joe Bay Buffer Preserve near Tyndall Air Force Base, Florida (upper right), and a northern cardinal (upper right, inset) caught at the location. Photos of Beale Air Force Base, California (lower left), and a Bullock's oriole (lower left, inset) caught at this location. Photographs by Timothy A. Bargar, U.S. Geological Survey. 


\section{Assessment of Bird Exposure to Lead at Tyndall and Beale Air Force Bases, 2016-17}

By Timothy A. Bargar

Prepared in cooperation with the

U.S. Fish and Wildlife Service and U.S. Air Force

Scientific Investigations Report 2018-5164 


\title{
U.S. Department of the Interior \\ DAVID BERNHARDT, Acting Secretary
}

\author{
U.S. Geological Survey \\ James F. Reilly II, Director
}

U.S. Geological Survey, Reston, Virginia: 2019

For more information on the USGS - the Federal source for science about the Earth, its natural and living resources, natural hazards, and the environment-visit https://www.usgs.gov or call 1-888-ASK-USGS.

For an overview of USGS information products, including maps, imagery, and publications,

visit https://store.usgs.gov.

Any use of trade, firm, or product names is for descriptive purposes only and does not imply endorsement by the U.S. Government.

Although this information product, for the most part, is in the public domain, it also may contain copyrighted materials as noted in the text. Permission to reproduce copyrighted items must be secured from the copyright owner.

Suggested citation:

Bargar, T.A., 2019, Assessment of bird exposure to lead at Tyndall and Beale Air Force Bases, 2016-17: U.S. Geological Survey Scientific Investigations Report 2018-5164, 30 p., https://doi.org/10.3133/sir20185164. 


\section{Acknowledgments}

This project could not have been completed without the assistance of numerous individuals. The authors thank Channing St. Aubin, Lorraine Ketzler, Todd Gerardot, Mark Cantrell, Patricia Kelly, Paul Lang, Lydia Ambrose, Peter Maholland, and Melody Ray-Culp of the of the Fish and Wildlife Service, Panama City Field Office, and Jennifer Brown of the Sacramento Field Office. Personnel of the U.S. Air Force who provided assistance are thanked, including Joe McLernan and Alex Bonner of the Tyndall Air Force Base and Darren Rector and Maia Lipschutz of the Beale Air Force Base. Thanks also go to U.S. Geological Survey personnel who provided assistance, including Carla Weiser and Tracy Fanara of the Wetland and Aquatic Research Center, Barnett Rattner and Sandra Schultz of the Patuxent Wildlife Research Center, and Dylan Shoemaker of the St. Joe Bay Buffer Preserve. This project was supported by U.S. Air Force military interdepartmental purchase request number F2MUAA5352GW01 and by funds appropriated to the Environmental Health Mission Area of the U.S. Geological Survey. 


\section{Contents}

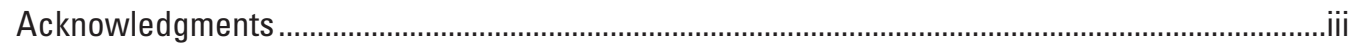

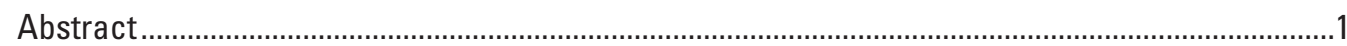

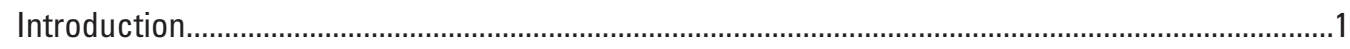

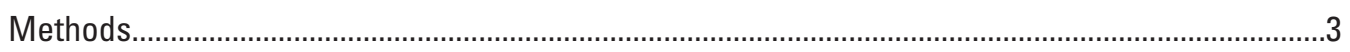

Sampling Design ...............................................................................................................

Capture of Birds and Measurement of their Exposure to Lead ...............................................

Collection and Analysis of Dietary Items for Lead .................................................................

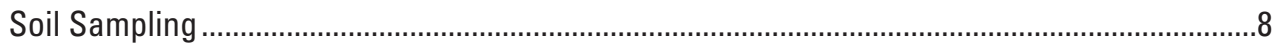

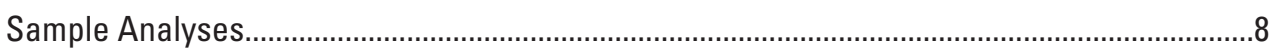

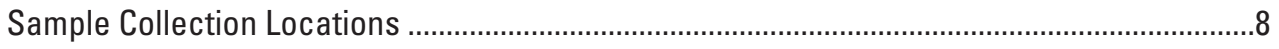

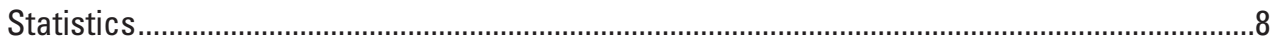

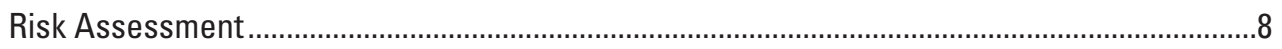

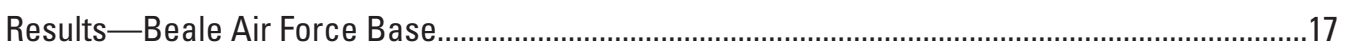

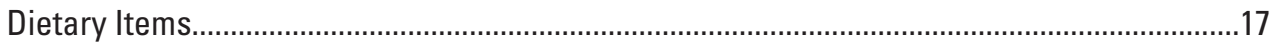

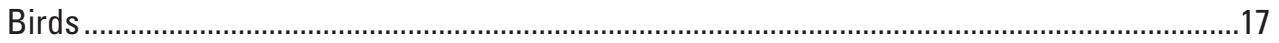

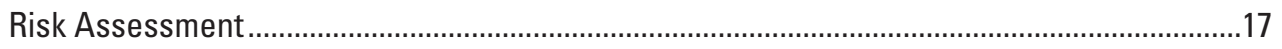

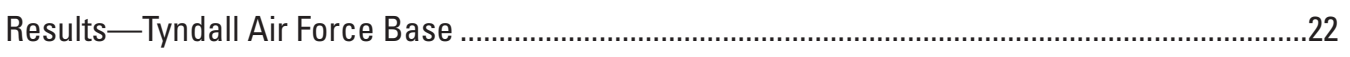

Dietary Items

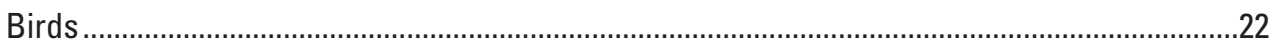

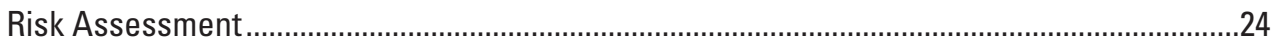

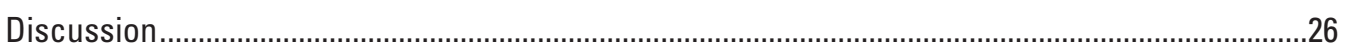

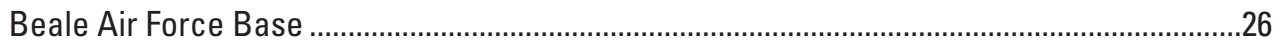

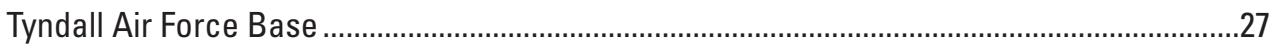

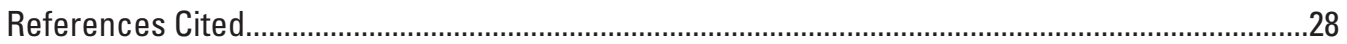




\section{Figures}

1. Map showing location of Beale Air Force Base, California 3

2. Map showing locations of Tyndall Air Force Base and St. Joe Bay Buffer Preserve, Florida .

3. Map showing location of assessment areas and reference area on Beale Air Force Base...

4. Map showing location of assessment area on Tyndall Air Force Base ...........................6

5. Photographs showing, $A$, a deployed light trap, and $B$, a pitfall trap along with representative samples from each trap.

6. Map showing location of sampling sites witin the assessment area of Tyndall Air Force Base for birds, seeds, pitfall traps, and light traps.

7. Maps showing location of sampling sites in the assessment areas of Beale Air Force Base: A, DP038, B, SR627 and SR594a, and C, ML586, ML585, and XU643b. .10

8. Maps showing locations of sampling sites in the reference areas of $A$, Beale Air Force Base, and B, St. Joe Bay Buffer Preserve for Tyndall Air Force Base. . .13

9. Graphs showing lead concentrations in dietary items collected at Beale Air Force Base and its reference area: $A$, invertebrates and $B$, seeds

10. Graph showing lead concentrations in blood collected from birds captured at Beale Air Force Base, California, and its reference area

11. Graph showing lead concentrations in feathers collected from birds captured at Beale Air Force Base, California, and its reference area

12. Graph showing $\delta$-aminolevulinic acid dehydratase activity in blood collected from birds captured at Beale Air Force Base, California, and its reference area..

13. Graph showing lead concentrations in blood of birds captured at Beale Air Force Base and its reference area, as well as for birds captured at Tyndall AFB and St. Joe Bay Buffer Preserve..

14. Graph showing lead concentrations in feathers of birds captured at Beale Air Force Base and its reference area, as well as for birds captured at Tyndall AFB and its reference area, St. Joe Bay Buffer Preserve

15. Graph showing lead concentrations in soils collected from the Beale Air Force Base reference area, California, and from areas A, B, C, and D of D-Street of Beale Air Force Base

16. Graph showing lead concentrations in dietary items collected from Tyndall Air Force Base and St. Joe Bay Buffer Preserve, Florida...

17. Graph showing lead concentrations in blood collected from birds captured at Tyndall Air Force Base and St. Joe Bay Buffer Preserve, Florida

18. Graph showing lead concentrations in feathers collected from birds captured at Tyndall Air Force Base and St. Joe Bay Buffer Preserve, Florida

19. Graph showing $\delta$-aminolevulinic acid dehytratase activity in blood collected from birds captured at Tyndall Air Force Base and St. Joe Bay Buffer Preserve, Florida

20. Graph showing lead concentrations in soils from Tyndall Air Force Base and St. Joe Bay Buffer Preserve, Florida... 


\section{Tables}

1. Potential guideline levels for lead concentrations in bird feathers and blood ..................2

2. Food ingestion rate, weight, and dietary composition of birds used

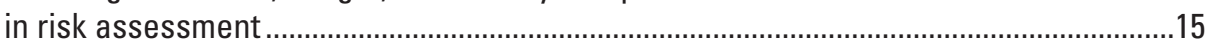

3. Variables for probabilistic risk assessment for different bird species............................16

4. Birds captured at Beale Air Force Base and the reference area, California ..................18

5. Likelihood that daily exposure of birds to lead at D-Street and Frisky Lake at Beale Air Force Base, California, exceeds the lowest observed adverse effect level

6. Birds captured at Tyndall Air Force Base and St. Joe Bay Buffer Preserve, Florida .

7. Likelihood that daily exposure of birds to lead at Tyndall Air Force Base and St. Joe Bay Buffer Preserve, Florida, exceeds the lowest observed adverse effect level. 


\section{Conversion Factors}

International System of Units to U.S. customary units

\begin{tabular}{|c|c|c|}
\hline Multiply & By & To obtain \\
\hline \multicolumn{3}{|c|}{ Length } \\
\hline meter (m) & 3.281 & foot $(\mathrm{ft})$ \\
\hline kilometer $(\mathrm{km})$ & 0.6214 & mile (mi) \\
\hline \multicolumn{3}{|c|}{ Area } \\
\hline square kilometer $\left(\mathrm{km}^{2}\right)$ & 0.3861 & square mile $\left(\mathrm{mi}^{2}\right)$ \\
\hline \multicolumn{3}{|c|}{ Volume } \\
\hline liter (L) & 2.113 & pint (pt) \\
\hline liter (L) & 1.057 & quart (qt) \\
\hline liter (L) & 0.2642 & gallon (gal) \\
\hline cubic decimeter $\left(\mathrm{dm}^{3}\right)$ & 0.2642 & gallon (gal) \\
\hline liter $(\mathrm{L})$ & 61.02 & cubic inch $\left(\mathrm{in}^{3}\right)$ \\
\hline cubic meter $\left(\mathrm{m}^{3}\right)$ & 35.31 & cubic foot $\left(\mathrm{ft}^{3}\right)$ \\
\hline cubic meter $\left(\mathrm{m}^{3}\right)$ & 1.308 & cubic yard $\left(\mathrm{yd}^{3}\right)$ \\
\hline cubic kilometer $\left(\mathrm{km}^{3}\right)$ & 0.2399 & cubic mile $\left(\mathrm{mi}^{3}\right)$ \\
\hline \multicolumn{3}{|c|}{ Mass } \\
\hline gram (g) & 0.03527 & ounce, avoirdupois (oz) \\
\hline kilogram (kg) & 2.205 & pound avoirdupois (lb) \\
\hline
\end{tabular}

\section{Datum}

Horizontal coordinate information is referenced to the North American Datum of 1983 (NAD 83).

\section{Supplemental Information}

Lead concentrations in soil, feathers, and dietary items (invertebrates and seeds) are given in parts per million (ppm) dry weight. Lead concentrations in blood are given as micrograms $(\mu \mathrm{g})$ per deciliter (dL) of blood. 


\section{Abbreviations}

\begin{tabular}{ll}
$\delta$-ALAD & $\delta$-aminolevulinic acid dehydratase \\
AFB & Air Force Base \\
bw & body weight \\
${ }^{\circ} \mathrm{C}$ & degrees Celsius \\
$\mathrm{cm}$ & centimeters \\
$\mathrm{dL}$ & deciliter \\
$\mathrm{dw}$ & dry weight \\
$\mathrm{Eco}-\mathrm{SSL}$ & ecological soil-screening level \\
$\mathrm{FIR}$ & food ingestion rate \\
$\mathrm{g}$ & grams \\
$\mathrm{h}$ & hours \\
$\mathrm{HC}$ & hazard concentration \\
$\mathrm{HCl}$ & hydrochloric acid \\
$\mathrm{M} \Omega$ & mega-ohms \\
$\mathrm{mg} / \mathrm{kg}$ & milligrams per kilogram \\
$\mathrm{NIST}$ & National Institute of Standards and Technology \\
$\mathrm{NOEC}$ & no observed effect concentration \\
$\mathrm{Pb}$ & lead \\
$\mathrm{ppb}$ & parts per billion \\
$\mathrm{ppm}$ & parts per million \\
$\mathrm{SCP}$ & scientific collecting permit \\
$\mathrm{SE}$ & standard error \\
$\mathrm{SJB}$ & St. Joe Bay Buffer Preserve \\
$\mathrm{TRV}$ & toxicity reference value \\
$\mu \mathrm{gg}$ & micrograms \\
$\mu \mathrm{g} / \mathrm{dL}$ & micrograms per deciliter \\
$\mu \mathrm{L}$ & microliters \\
\hline
\end{tabular}




\title{
Assessment of Bird Exposure to Lead at Tyndall and Beale Air Force Bases, 2016-17
}

\author{
By Timothy A. Bargar
}

\section{Abstract}

Soil contamination by lead $(\mathrm{Pb})$ from past small munitions training on Beale Air Force Base, California, and Tyndall Air Force Base, Florida, may result in adverse effects for passerine birds that utilize the locations. A study was conducted during 2016-17 by the U.S. Geological Survey, in cooperation with the U.S. Fish and Wildlife Service and U.S. Air Force, at both Air Force Bases (AFBs) to assess the risk of bird exposure to $\mathrm{Pb}$. Two different methods were used to estimate exposure. The first was analysis of blood and feather samples collected from birds captured on both AFBs, and the second was food chain modeling using data on $\mathrm{Pb}$ concentrations in dietary items (invertebrates and seeds) collected from both AFBs. Lead concentrations in blood and feathers for birds captured at Beale AFB indicate low exposure and risk; potential toxicity is possible based on blood and feather data for birds from Tyndall AFB. Food chain modeling utilizing dietary contamination indicates a risk likelihood of up to 35 percent at Beale AFB and up to 34 percent at Tyndall AFB. Lead exposure from incidental soil ingestion increased risk likelihood at both AFBs and is a significant uncertainty in this risk assessment. A companion data release for data collected during this project can be found at https://doi.org/10.5066/P92YXMQ2.

\section{Introduction}

Lead $(\mathrm{Pb})$ is a widely encountered natural element. It is found at a range of concentrations in different components of the ecosystem. The average concentration among the soils and bedrock of the Earth is 15 parts per million (ppm; Lovering, 1976). In the United States, the statewide average in soils ranges from 6.2 (Florida) to 55.0 milligrams per kilogram (mg/kg; Pennsylvania) (https://www.epa.gov/superfund/usgsbackground-soil-lead-survey-state-data). Lead concentrations in vascular plants can vary depending on the soil $\mathrm{Pb}$ levels but can range from 15 to $50 \mathrm{ppm}$ in uncontaminated locations (Lovering, 1976). Despite being a naturally occurring element, $\mathrm{Pb}$ is one of a few heavy metals in the environment that has no biological role (Goyer, 1986).

Human activities, such as mining (Pavlowsky and others, 2017), fossil fuel combustion (Kristensen 2015), discharge of lead-based ammunition, fishing with lead-based weights, and use of lead-based paints (Laidlaw and others, 2017), can result in $\mathrm{Pb}$ concentrations exceeding background. Manufacture and use of some of the lead-based products have decreased or been phased out (fuels, ammunition, fishing weights, and paint) to reduce environmental contamination. However, contamination from ongoing and past activities has raised concerns for biological systems.

Lead toxicity in birds is a well-researched subject. It was perhaps first reported in the late 1800s when Hough and Grinnel (1894) reported finding Pb shot in gizzards of ducks, geese, and swans that exhibited outward signs of what was later diagnosed as lead toxicosis. Hough and Grinnel (1894) hypothesized that the afflicted waterfowl either incidentally or purposely ingested lead shot from wetland sediments and later succumbed to lead poisoning. That hypothesis was later proven to be true, which led to the ban of $\mathrm{Pb}$-based shot for hunting waterfowl. Of course, birds can accumulate $\mathrm{Pb}$ from routes other than lead pellet ingestion. As a result, numerous investigations have focused on $\mathrm{Pb}$ toxicity to birds (VallverduColl and others, 2015; Beyer and others, 2014; Kerr and others, 2011; Schulz and others, 2006; Hoffman and others, 2000; Beyer and others, 1988; Anders and others, 1982; Dieter and Finley, 1979). Health endpoints affected by $\mathrm{Pb}$ in those investigations included blood biochemistry $(\delta$-aminolevulinic acid dehytratase activity, protoporphyrin level, erythrocyte content, and oxidative stress) (Beyer and others, 1988; Dieter and Finley, 1979), immunocompetence (Vallverdu-Coll and others, 2015), histopathology (Beyer and others, 1988), body weight (Vallverdu-Coll and others, 2015; Beyer and others, 1988), and mortality (Vallverdu-Coll and others, 2015; Hoffman and others, 2000; Beyer and others, 1988).

Concerns for $\mathrm{Pb}$ toxicity to wild birds have led to the development of guideline exposure levels that can be used to estimate risk for birds in areas of known or suspected $\mathrm{Pb}$ contamination. Non-lethal assessments of avian exposure to $\mathrm{Pb}$ involve the collection and analysis of feathers and blood. $\mathrm{Pb}$ concentrations in feathers and blood then are compared with concentrations associated with effects. Although field studies have found elevated $\mathrm{Pb}$ concentrations in feathers (Bauerová and others, 2017; Cooper and others, 2017; Burger and Gochfeld, 2000; Goede and de Bruin, 1984), few studies report an association between $\mathrm{Pb}$ concentrations in feathers and toxic effects. Burger and Gochfeld (2000) and Tsipoura 
and others (2011) note that $4 \mathrm{ppm}$ of $\mathrm{Pb}$ in feathers was associated with adverse effects on behavior and physiology, as well as reduced nestling survival. Golden and others (2003) report $\delta$-aminolevulinic acid dehytratase $(\delta$-ALAD) depression when $\mathrm{Pb}$ concentrations in feathers equaled approximately $2 \mathrm{ppm}$. One of the criticisms for using feathers in exposure assessments is the possibility that external contamination (that is, soiling of the feathers) could give a false indication of an internal exposure level. No regulatory guidelines have been identified for $\mathrm{Pb}$ concentrations in feathers.

Many researchers have reported on the relation between $\mathrm{Pb}$ concentrations in blood and toxic effects. Those concentrations are relatively consistent and largely reference a few papers (table 1). Buekers and others (2009) did not suggest levels of clinical diagnoses, but rather recommended a blood $\mathrm{Pb}$ concentration of 71 micrograms per deciliter $(\mu \mathrm{g} / \mathrm{dL}$; 90 percent confidence interval of $26-116 \mu \mathrm{g} / \mathrm{dL}$ ) as an $\mathrm{HC}_{5}$ (the 5th percentile of no observed effect concentrations reported in the literature) to protect birds from the adverse effects of $\mathrm{Pb}$ on growth, reproduction, hematology, and physiology. Lastly, Johnson and others (2007) estimated Pb concentrations in blood of 29 and $58 \mu \mathrm{g} / \mathrm{dL}$ as the no observed and lowest observed adverse effect levels for birds, respectively. These suggested guideline levels enable biologists to infer the risk of $\mathrm{Pb}$ exposure for birds based on the non-lethal collection and analysis of blood. As is the case for feathers, no regulatory levels have been recommended for $\mathrm{Pb}$ in avian blood.

$\delta$-Aminolevulinic acid dehytratase $(\delta$-ALAD) is an enzyme found in blood cells and other tissues involved in porphyrin biosynthesis. Measured levels of $\delta$-ALAD activity in avian blood are often used to determine exposure and possible $\mathrm{Pb}$ toxicity because of its sensitivity to $\mathrm{Pb}$ (Sakai and others, 1983; Dieter and Finley, 1979; Hernberg and others, 1970). Disruption of that enzyme is proportional to $\mathrm{Pb}$ concentrations in blood from approximately $5 \mu \mathrm{g} / \mathrm{dL}$ (Pain, 1989; Hernberg and others, 1970) up to $150 \mu \mathrm{g} / \mathrm{dL}$ (Pain 1989). Severe clinical or lethal exposures are the diagnoses when the $\mathrm{Pb}$ concentration in the blood reaches $150 \mu \mathrm{g} / \mathrm{dL}$. No further inhibition occurs at greater $\mathrm{Pb}$ concentrations. Disruption of $\delta$-ALAD activity reduces porphyrin biosynthesis leading to porphyria, anemia, and lethargy (Eisler, 1988). The combination of $\mathrm{Pb}$ concentrations in blood and $\delta$-ALAD activity provides a good diagnosis of the likelihood of $\mathrm{Pb}$ toxicity for birds.

Despite the uncertainties associated with estimating bioavailability to birds of soil-associated $\mathrm{Pb}$, regulatory guidelines have been suggested for $\mathrm{Pb}$ concentrations in soil (for example, U.S. Environmental Protection Agency [EPA] Ecological Soil Screening Levels [Eco-SSL]; EPA, 2005). The guideline values derived for ground-feeding insectivorous, herbivorous, and carnivorous birds by the EPA are 11, 46, and $510 \mathrm{mg} / \mathrm{kg}$ dry weight (dw), respectively. These guideline values were calculated for a single species representative of ground-feeding avian insectivores (Scolopax minor [American woodcock]) feeding exclusively on earthworms, a granivore (Zenaida macroura [mourning dove]) feeding only on seeds, and a carnivore (Buteo jamaicensis [red-tailed hawk]) feeding
Table 1. Potential guideline levels for lead concentrations in bird feathers and blood.

[ppm, parts per million; ALAD, aminolevulinic acid dehytratase; $\mu \mathrm{g} / \mathrm{dL}$, microgram per deciliter; $\mathrm{HC}_{5}$, hazardous concentration fifth percentile; NOAEL, no observed adverse effect level; LOAEL, lowest observed adverse effect level; <, less than; >, greater than]

\begin{tabular}{|c|c|c|}
\hline $\begin{array}{l}\text { Lead concentration } \\
\text { in bird feathers } \\
\text { (ppm dry weight) }\end{array}$ & Effect & Reference \\
\hline 4 & $\begin{array}{l}\text { Altered behavior } \\
\text { and physiology }\end{array}$ & $\begin{array}{l}\text { Burger and Gochfeld, } \\
\quad 2000\end{array}$ \\
\hline 2 & ALAD depression & Golden and others, 2003 \\
\hline $\begin{array}{c}\text { Lead concentration } \\
\text { in bird blood } \\
(\mu \mathrm{g} / \mathrm{dL})\end{array}$ & Diagnosis & Reference \\
\hline 71 & $\mathrm{HC}_{5}$ & Buekers and others, 2009 \\
\hline 29 & NOAEL & Johnson and others, 2007 \\
\hline 58 & LOAEL & Johnson and others, 2007 \\
\hline$<20$ & Background & $\begin{array}{l}\text { Kramer and Redig, 1997; } \\
\text { Franson and Pain, } 2011\end{array}$ \\
\hline $20-60$ & Subclinical & Kramer and Redig, 1997 \\
\hline $20-50$ & Subclinical & Franson and Pain, 2011 \\
\hline $61-120$ & Clinical (treatable) & Kramer and Redig, 1997 \\
\hline $50-100$ & Clinical (treatable) & Franson and Pain, 2011 \\
\hline$>100$ & Severe clinical & Franson and Pain, 2011 \\
\hline$>120$ & Lethal & Kramer and Redig, 1997 \\
\hline$>150$ & Lethal & Pain, 1989 \\
\hline
\end{tabular}

only on small mammals. The values for the herbivores and carnivores are greater than the 95th percentile for background $\mathrm{Pb}$ concentrations in U.S. soils, whereas the value for avian insectivores is less than the 50th percentile for background $\mathrm{Pb}$ concentrations (EPA, 2005). As the term "guideline" implies, these values are meant to be screening values and were not intended as standards to be used for setting clean-up levels (EPA, 1993).

Areas of Tyndall Air Force Base (AFB) near Panama City, Florida, have historically been used for small arms training. Soils in those areas are currently contaminated with spent ammunition from past training, which resulted in elevated $\mathrm{Pb}$ concentrations that may present a risk for birds utilizing the areas. Small arms training also historically occurred at specific 
locations on Beale AFB near Yuba City, California, but in contrast to $\mathrm{Pb}$-contaminated areas at Tyndall AFB, contaminated soils at Beale AFB have been delineated and remediated. However, concerns remain that birds utilizing the remediated areas may be at risk from remaining $\mathrm{Pb}$ contamination.

This report presents and discusses data from the assessment of $\mathrm{Pb}$ risk to passerine birds at Tyndall and Beale Air Force Bases conducted in 2016 and 2017 by the U.S. Geological Survey in cooperation with the U.S. Fish and Wildlife Service and U.S. Air Force. Concentrations of $\mathrm{Pb}$ in the blood as well as $\delta$-ALAD activity were measured for birds captured at the two AFBs to understand the risk of $\mathrm{Pb}$ for the birds. In addition, radiographs were generated for the captured birds to determine the presence of ingested $\mathrm{Pb}$ shot. Because $\mathrm{Pb}$ in the blood is an indicator of relatively recent contamination (1-2 months), feathers were collected from each bird for analysis of $\mathrm{Pb}$ content as an indicator of longer term $\mathrm{Pb}$ contamination (life span of the feather of up to 1 year). Lastly, dietary items (invertebrates and seeds) were collected and analyzed for $\mathrm{Pb}$ contamination to gain insight into dietary exposure. Lead contamination in birds, $\delta$-ALAD activity, and $\mathrm{Pb}$ contamination of dietary items were compared between the contaminated areas of the AFBs and reference areas. $\mathrm{Pb}$ concentrations in feathers and blood, and soil and dietary items, are presented in tables and figures. $\mathrm{Pb}$ concentrations in invertebrates and seeds are presented in figures.

\section{Methods}

\section{Sampling Design}

This project was conducted at Beale AFB near Yuba City, California (fig. 1); Tyndall AFB near Panama City, Florida; and St. Joe Bay Buffer Preserve (SJB) near Port St. Joe, Florida (fig. 2). Past small arms training on Beale and Tyndall AFBs has contaminated soils with $\mathrm{Pb}$ from spent munitions. The $\mathrm{Pb}$ contamination may affect passerine bird species that utilize the contaminated habitats.

Areas of the AFBs that were assessed during the project are denoted in figures 3 (Beale AFB) and 4 (Tyndall AFB). The three areas of Beale AFB that were assessed in this project are D-Street (DP038), Frisky Lake (SR627/SR594a), and Warren Shingle Road (ML586/ML585/XU643b). Only a single area on Tyndall AFB (SR170/FR038/SR181) was assessed. These areas either have (Beale AFB) or have not (Tyndall AFB) been remediated for $\mathrm{Pb}$ contamination in soils. In both cases, the areas are referenced in this report for simplicity as suspect areas. Reference areas for each AFB were chosen on the basis of similarity of habitat and likelihood of low impact from $\mathrm{Pb}$ contamination. $\mathrm{SJB}$ was chosen as the reference area for Tyndall AFB, whereas the southeastern part of Beale AFB was chosen as the reference area for the $\mathrm{Pb}$-impacted areas of Beale AFB. Hunting activities in both reference areas in the past may have resulted in some $\mathrm{Pb}$ contamination. However, contamination is presumed to be at lower levels than in the suspect areas.

Three goals served as the basis of the sampling design for this project - comparing $\mathrm{Pb}$ contamination among the suspect areas and the reference areas, measuring current avian exposure to $\mathrm{Pb}$, and estimating risk of $\mathrm{Pb}$ to birds. Avian exposure was measured by collecting blood and feathers and analyzing them for $\mathrm{Pb}$ concentrations, and by taking radiographs of captured birds to detect the presence of $\mathrm{Pb}$ shot pellets in the gizzard. Dietary items (seeds and invertebrates) were collected and analyzed for $\mathrm{Pb}$ concentrations to estimate exposure for birds that may forage on the suspect areas and for comparison of $\mathrm{Pb}$ contamination among the suspect and reference areas.

\section{Capture of Birds and Measurement of their Exposure to Lead}

Avian exposure to $\mathrm{Pb}$ on the AFBs was measured by analysis of blood and feathers non-lethally collected from captured birds. Birds were captured (California SCP-13556, Migratory Bird permit MB02949C-0) by one of three methods - mist netting, baited box traps, or monofilament leg snares. All three trap types were placed at multiple locations within the assessment and reference areas. Mist nets were used at Beale and Tyndall AFBs in addition to the reference areas. Although box traps and leg snares were used at all areas, neither were successful at Beale AFB and its associated reference area. Mist

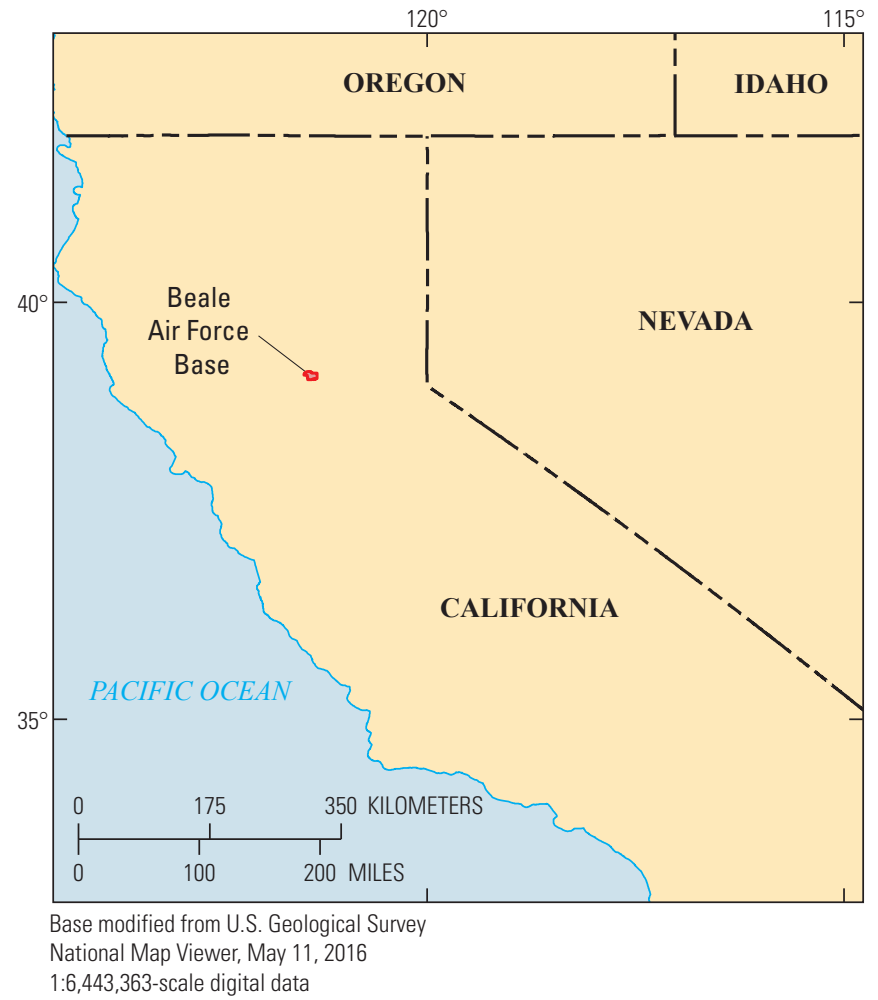

Figure 1. Location of Beale Air Force Base, California. 


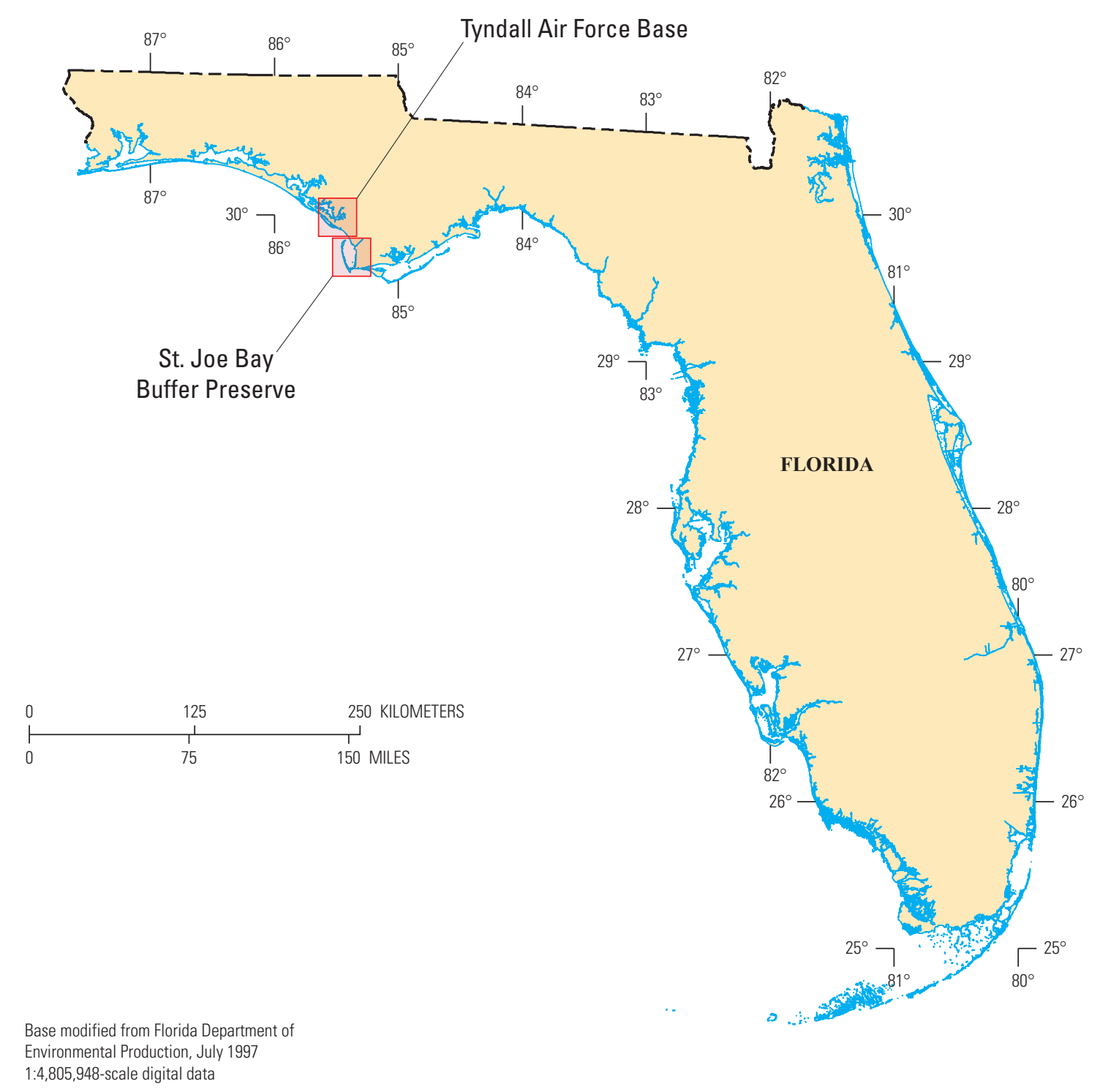

Figure 2. Locations of Tyndall Air Force Base and St. Joe Bay Buffer Preserve, Florida.

nets were placed near structures (shrubs and trees) to capture birds attracted to the structure. The nets were erected during the pre-dawn hours and were monitored continuously until $4 \mathrm{~h}$ after sunrise, at which time the nets were closed. Birds trapped in the nets, in the box, or by the snares were removed as soon as they were discovered, usually within 5 minutes of being trapped. The retrieved birds were placed into canvas bags, then into cardboard boxes, and taken to the field laboratory (transit time of 5-10 minutes). While still in the canvas bags, radiographs (ImageX-1417 paired with PXM-20BT X-Ray source) were taken of the birds for later analysis for the presence of $\mathrm{Pb}$ shot. Afterwards, the birds were weighed to the nearest gram (g) to determine the maximum blood volume to be drawn (for example, 20 -g bird x $0.01=0.2$ milliliter $(\mathrm{mL})$ maximum blood volume assuming $1 \mathrm{~g}$ blood approximates $1 \mathrm{~mL}$ blood). After being weighed, the birds were removed from the canvas bag and blood was drawn using a heparinized 24-gauge needle inserted bevel down into the left jugular vein. Afterwards, breast feathers were collected, and the birds were placed back into the canvas bag, and then the cardboard box, for return to the capture location.

The collected blood samples were transferred to a cryovial from which 50 microliters $(\mu \mathrm{L})$ was taken for measurement of $\mathrm{Pb}$ concentrations. Measurement of $\mathrm{Pb}$ concentrations is described in section "Sample Analyses." In addition to the sample taken for analysis of $\mathrm{Pb}$, a small portion of blood was drawn into a hematocrit tube for determination of sedimentation rate, and then hematocrit, using a capillary micro-hematocrit reader after centrifugation at 12,000 times gravity for 5 minutes (Unico Model C-MH30 micro-hematocrit centrifuge). Hemoglobin content was also determined (HemoCue $\mathrm{Hb} 201+$ ). Hematocrit was not measured for birds collected at 


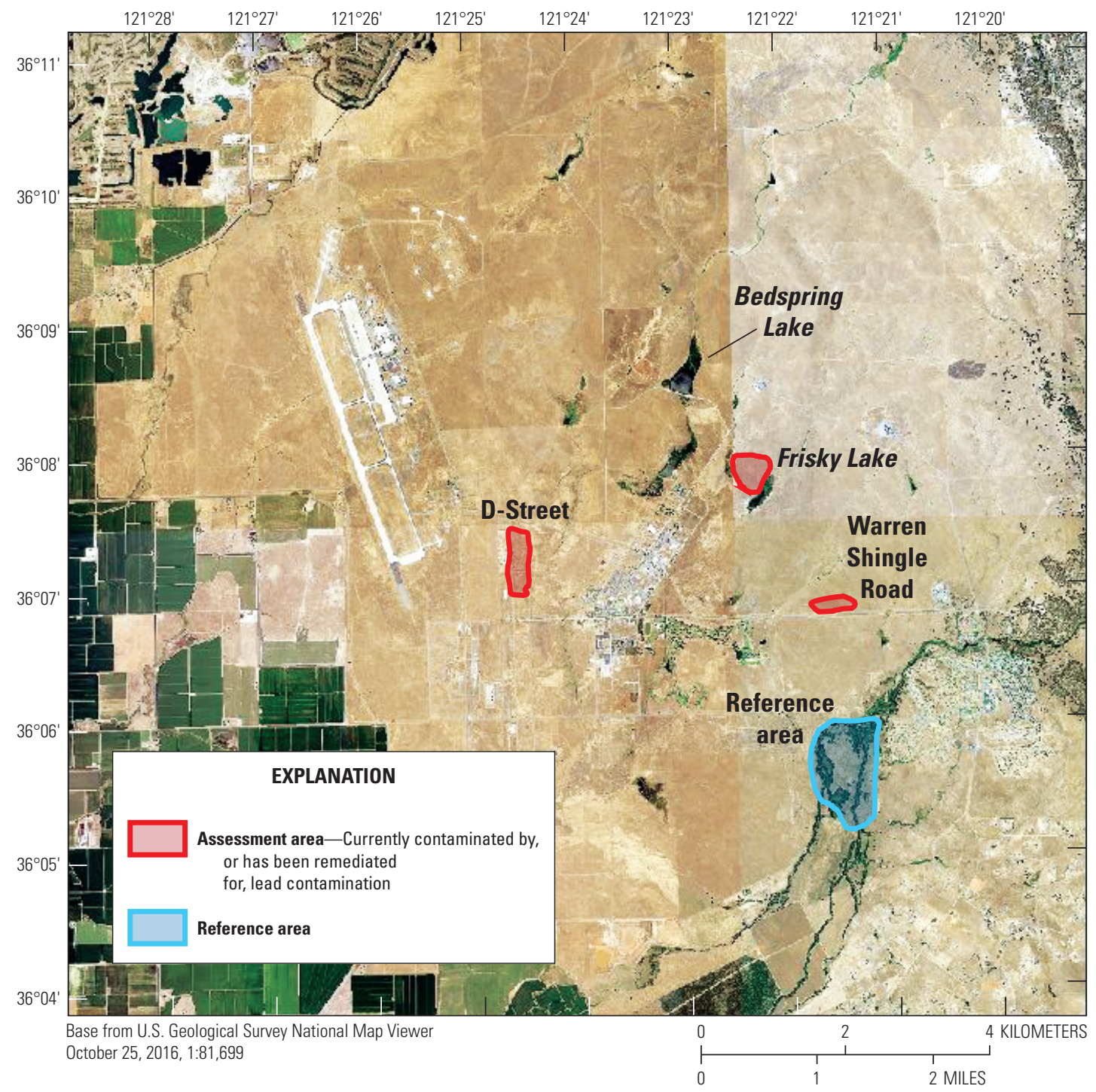

Figure 3. Location of assessment areas and reference area on Beale Air Force Base.

Tyndall AFB. The remaining blood was placed on dry ice and later placed into a freezer at -80 degrees Celsius $\left({ }^{\circ} \mathrm{C}\right)$ until it could be analyzed for $\delta$-ALAD activity.

$\delta$-ALAD activity in blood was measured to assess potential toxic response from $\mathrm{Pb}$ exposure. The sample preparation and analysis procedure followed U.S. Geological Survey Patuxent Wildlife Research Center Standard Operating Procedure number TOP 1991 . Thawed blood $(25 \mu \mathrm{L})$ was pipetted into double-distilled water $(350 \mu \mathrm{L})$, vortexed, and incubated for 10 minutes at $38^{\circ} \mathrm{C}$. After the addition of aminolevulinic acid $(250 \mu \mathrm{L})$, the sample was incubated in the dark for 1 hour at $38^{\circ} \mathrm{C}$. The sample was then vortexed after adding 10 -percent trichloroacetic acid $(250 \mu \mathrm{L})$ and centrifuged for 10 minutes at 1,500 times gravity. Along with $100 \mu \mathrm{L}$ of Ehrlich's reagent, $100 \mu \mathrm{L}$ of the sample was added to a well on a 96-well plate. After shaking the plate for 20 seconds, absorbance at 555 nanometers relative to water was measured using an Epoch Microplate Spectrophotometer paired with BioTek Gen5 software (Version 2.07). $\delta$-ALAD activity was expressed as nanomolar (nM) aminolevulinic acid per minute per $\mathrm{mL}$ of red blood cells (RBC) and was calculated according to Berlin and Schaller (1974) with modifications for the microplate procedure described above. Activity for birds captured at Tyndall AFB for which hematocrit was not measured was calculated using preferably the average hematocrit for the same species captured elsewhere or the average hematocrit for other birds captured in the reference area. For example, the average hematocrit for Cardinalis cardinalis (northern cardinals) captured at SJB was used to calculate activity for northern cardinals captured at Tyndall AFB, but the average for all birds captured at SJB was used for Vireo griseus (white-eyed vireo) captured at Tyndall AFB. 


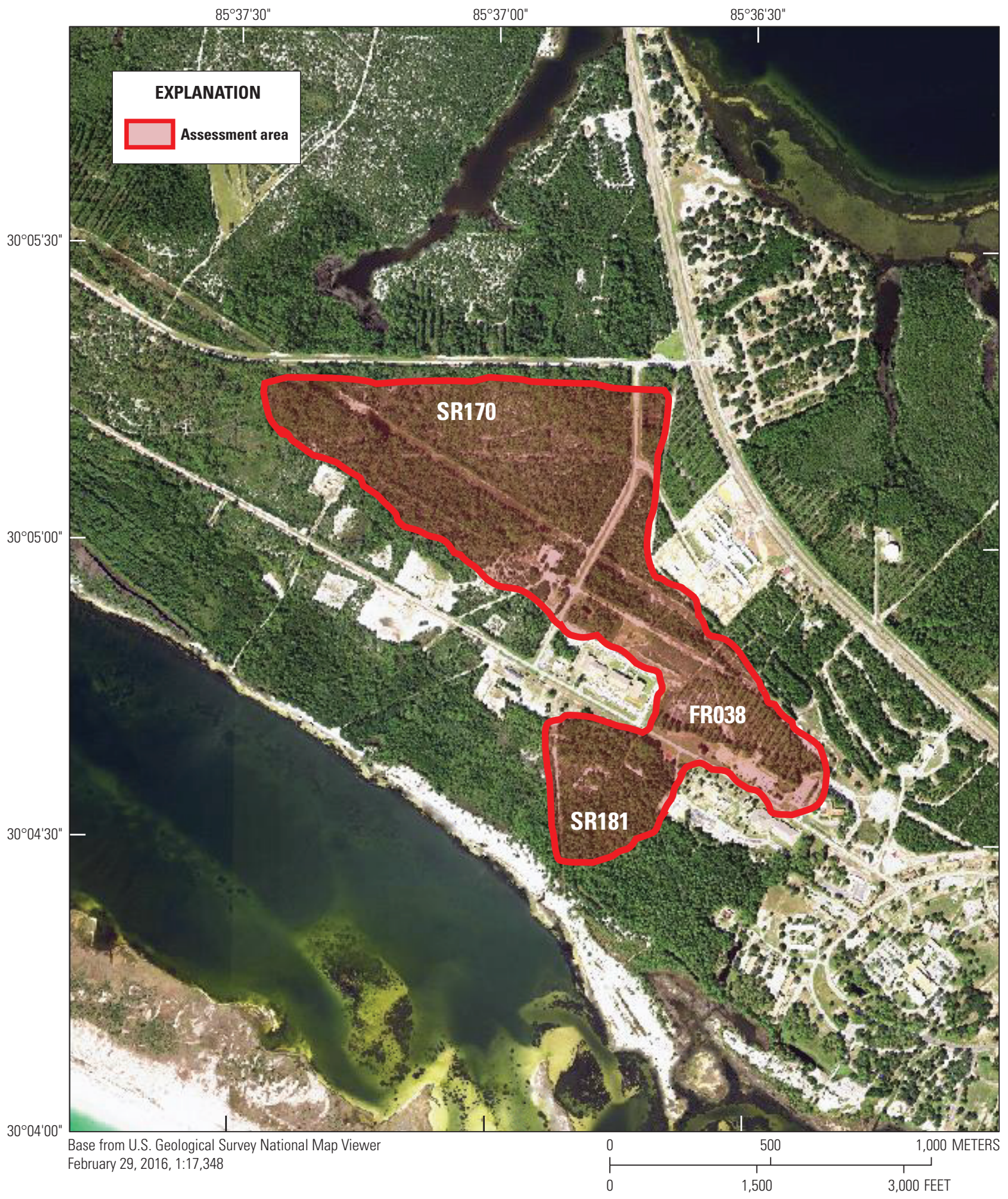

Figure 4. Location of assessment area on Tyndall Air Force Base. 


\section{Collection and Analysis of Dietary Items for Lead}

In addition to measurement of $\mathrm{Pb}$ concentrations in birds and estimation of toxic response in birds by measurement of $\delta$-ALAD activity in blood, potential dietary items (invertebrates and seeds) were collected and analyzed for $\mathrm{Pb}$ to estimate exposure of birds that may exclusively forage on the $\mathrm{Pb}$-contaminated areas. Three different methods were used to collect invertebrates - light traps, pitfall traps, and nets. Light traps (fig. 5) were deployed for a single night at multiple locations in $\mathrm{Pb}$-contaminated and reference areas to collect night-flying phototaxic invertebrates. The traps were battery powered, deployed shortly before dark, and left to operate until the battery power was drained (approximately $8 \mathrm{~h}$ ). Invertebrates attracted to the light were deflected down into a net in the lower chamber of the trap and euthanized by a chemical fumigant (Hot Shot ${ }^{\mathrm{TM}}$, active ingredient dichlorvos) placed within the chamber. Pitfall traps (fig. 5) were used to capture soil-associated invertebrates. The traps were deployed at multiple locations either in triplicate for a $24 \mathrm{~h}$ period (Beale and Tyndall AFBs, and Beale reference area) or singly for 3 consecutive days (St. Joe Bay Buffer Preserve) to insure sampling for 3 trap days at each location. Invertebrates captured by the light traps were sieved to separate those smaller than about 2 millimeters from the remaining invertebrates and composited into an "unsorted" invertebrate sample. The larger invertebrates were sorted into orders (for example, Coleoptera, Lepidoptera, Orthoptera) to allow assessment of the possible role that feeding at different niches and trophic levels would have on $\mathrm{Pb}$ concentrations in the invertebrates. Invertebrates in the pitfall traps were composited to increase invertebrate mass for analysis and were not sorted into orders. Nets were used to sweep herbaceous vegetation at Beale AFB to capture grasshoppers (order Orthoptera), which were highly abundant during field sampling. The sorted invertebrates were placed into Ziploc bags and sent to the contracted laboratory for analysis.

No single plant species was sought for seed collection because no assumption was made about seed preference(s) by any bird species. Therefore, we collected as many seeds as possible from a variety of plants to encompass variation among plant species for $\mathrm{Pb}$ translocation from roots to seeds. Two people each spent 5 minutes collecting seeds from a location to standardize the collection effort among locations as well as assessment and reference areas. All seeds from a location were composited into a single Ziploc bag and sent to the contract laboratory for analysis.
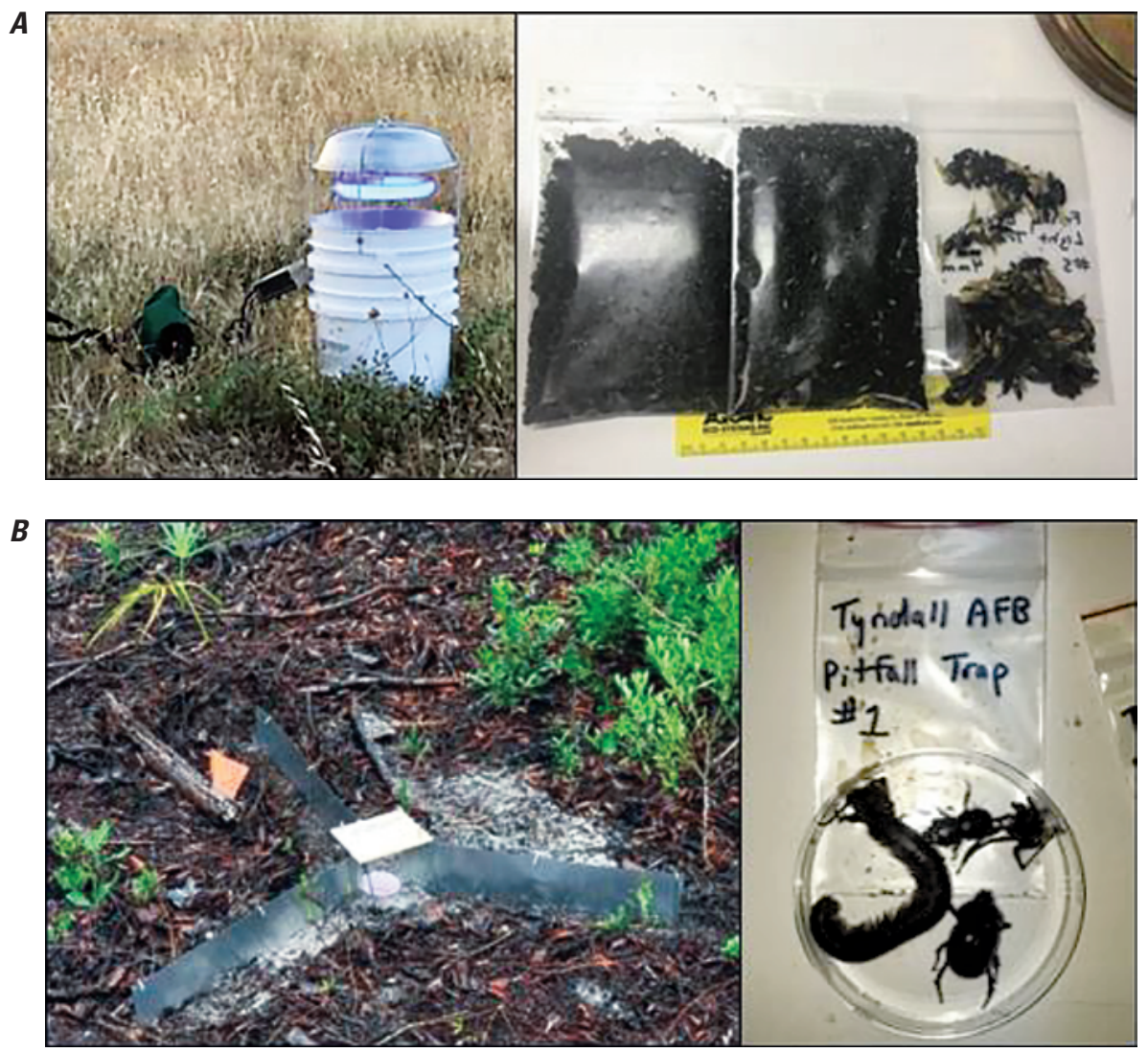

Figure 5. $A$, a deployed light trap, and $B$, a pitfall trap along with representative samples from each trap. 


\section{Soil Sampling}

Soils were collected from 10 randomly selected locations within each of the reference areas for comparison with $\mathrm{Pb}$-contaminated soils in the suspect areas. Soil sampling in the suspect areas was not part of the present study. It was conducted previously by commercial contractors selected by the U.S. Air Force. Data for the discussion in this report of $\mathrm{Pb}$ concentrations in soils in the suspect areas of Tyndall and Beale AFBs were provided by employees at Tyndall and Beale AFBs.

\section{Sample Analyses}

Feather samples were sonicated (Branson 1510 ultrasonic bath) and rinsed with deionized water, and then freeze dried prior to digestion. All tissue samples (that is, invertebrates and seeds) were digested with trace-metals grade nitric and hydrochloric acids (EMD Millipore) and hydrogen peroxide (J.T. Baker), diluted to volume with ultrapure water (Type 1, 18.2 Mega ohms per centimeter resistivity), and then analyzed for $\mathrm{Pb}$, and in some cases aluminum, on a Perkin Elmer DRC 2 inductively coupled plasma-mass spectrometer. External contamination is indicated by elevated aluminum concentrations. Laboratory quality control samples accompanied project samples through preparation and analysis steps and included method blanks, spiked blanks (laboratory control samples), duplicate samples, spiked samples, and certified reference materials. National Institute of Standards and Technology (NIST) standard 955c was the standard reference material used for blood, whereas NIST 2976 was used for other tissues. The marine sediment reference materials MESS-3 was used for soil samples. Analytical accuracy of the methods was estimated as 81, 106, and 107 percent for MESS-3, NIST 2976, and NIST 955c, respectively. Precision (percent relative difference between samples and their duplicates) for analyses was estimated to be 1, 4, 1, and 4 percent for soil, seed, invertebrate, and blood samples, respectively. Method detection limits (concentration in the matrix) were 291, 47, 49, and 0.5 parts per billion wet weight for soil, seeds, invertebrates, and blood, respectively. The moisture content of samples was determined by weight loss through freeze drying using a Labconco Freezone 12L lyophilizer.

\section{Sample Collection Locations}

Sampling sites on Tyndall and Beale AFBs are shown in figures 6 and 7, respectively, whereas sampling sites in the reference areas are shown in figure 8 . Note that pitfall traps were not deployed at the Frisky Lake (SR627/SR594a) or Warren Shingle Road (ML586/ML585/XU643b) areas of Beale AFB because the soil in those areas was too hard. Also note that no bird traps were deployed at D-Street (DP038) or Warren Shingle Road of Beale AFB. Both of those areas lacked structure that could attract birds and that could conceal mist nets.

\section{Statistics}

Lead concentrations in dietary items as well as $\delta$-ALAD activity were compared among the suspect and reference areas for Tyndall and Beale AFBs. Parametric methods (Analysis of Variance) were used for the comparisons if assumptions could be satisfied; nonparametric methods (Kruskal-Wallis test) were used otherwise. Lead concentrations in blood and feathers were compared between Tyndall AFB and St. Joe Bay Buffer Preserve only for the same species. All comparisons were at a significance level of $\alpha=0.05$. Significant differences for the comparisons were noted in the subsequent discussion when $p$-values were less than the significance level $(\alpha=0.05)$.

\section{Risk Assessment}

Two methods were used to estimate risk of $\mathrm{Pb}$ to birds on the AFBs. In the first method, the risk for birds captured on the AFBs was based on guideline levels for $\mathrm{Pb}$ concentrations in blood (Buekers and others, 2009; Johnson and others, 2007) and on Eco-SSL levels for $\mathrm{Pb}$ concentrations in soil (EPA, 2005). Frequency distributions were generated for $\mathrm{Pb}$ concentrations in blood, feathers, and soils, and then were compared to concentrations considered indicative of varying degrees of toxicity (Franson and Pain, 2011; Buekers and others, 2009; Johnson and others, 2007; EPA, 2005; Kramer and Redig, 1997).

In the second method, risk for birds that may forage in the suspect areas was estimated only on the basis of consumption of $\mathrm{Pb}$-contaminated food and incidental ingestion of $\mathrm{Pb}-$ contaminated soil. Exposure from $\mathrm{Pb}$-contaminated respirable particulates, water, and passage through the dermis was not considered. The focal species chosen for this risk assessment are listed in table 2. Risk for passerine and non-passerine birds was based on food ingestion rates (FIR) calculated using equations 3-4 and 3-5 in the EPA handbook (EPA, 1993), published weight data for species commonly observed at the AFBs (table 2), Pb-contamination of dietary items collected and analyzed during this project, available information on dietary preferences, published information on incidental soil ingestion rates (Beyer and others, 1994), and toxicity reference values ( $\mathrm{mg} / \mathrm{kg}$ body weight per day) compiled by EPA (2005). The toxicity reference values were segregated into two broad effects categories. The first (Category 1 ) included biochemical, physiological, pathological, and behavioral effects, and the second (Category 2) included reproductive, growth, and survival effects. The potential for factors outside of those areas to enhance or reduce risk was not considered.

A tiered approach was used in the risk assessment. A conservative screening level risk assessment was conducted initially. The estimated risk was calculated on the basis of the peak measured $\mathrm{Pb}$ concentrations for dietary items and soil, smallest body weight for birds, highest reported incidental soil ingestion proportion for birds (0.3), and the lowest toxicity reference value (TRV). 


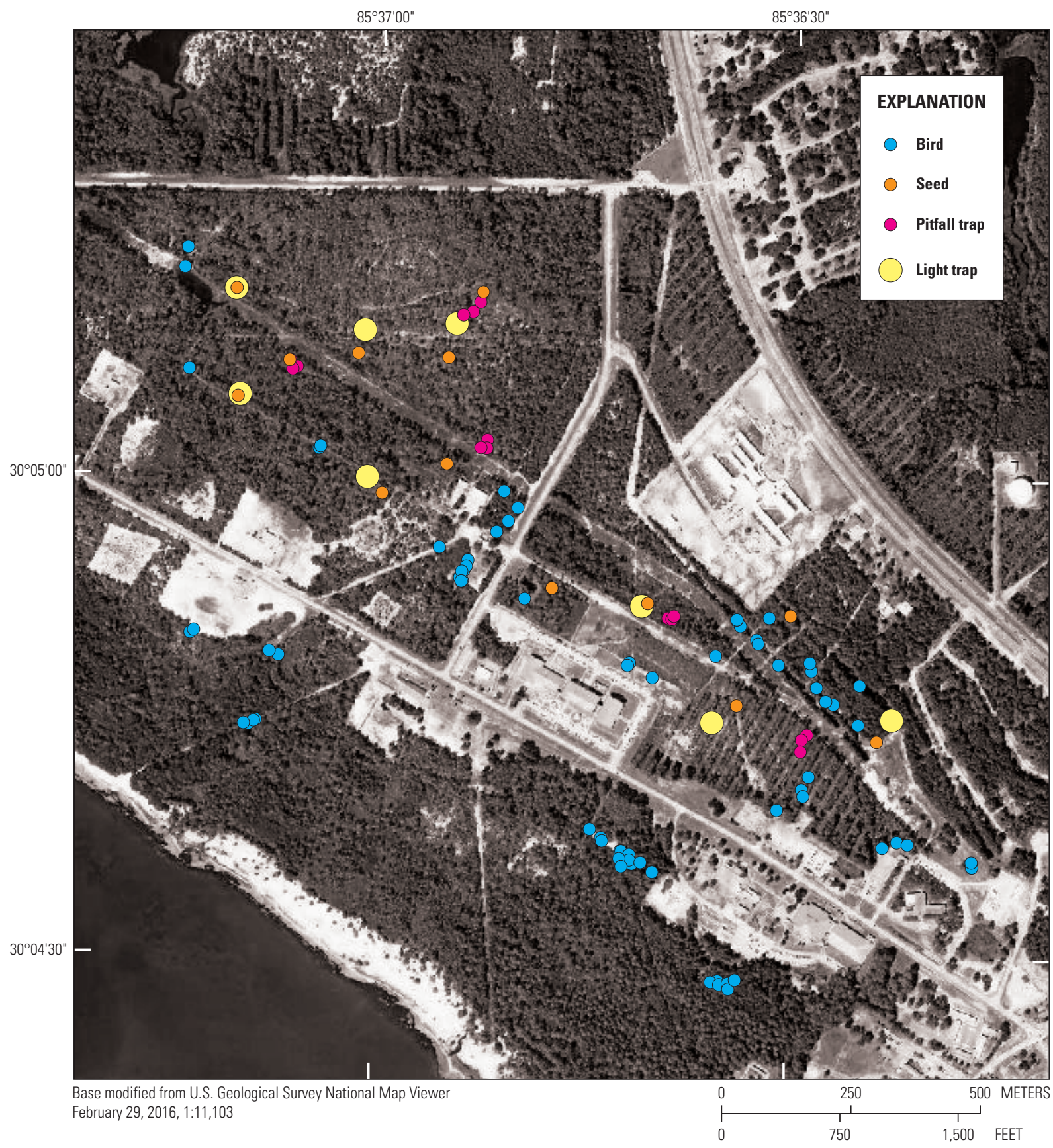

Figure 6. Location of sampling sites witin the assessment area of Tyndall Air Force Base for birds, seeds, pitfall traps, and light traps. 


\section{A, DP038}

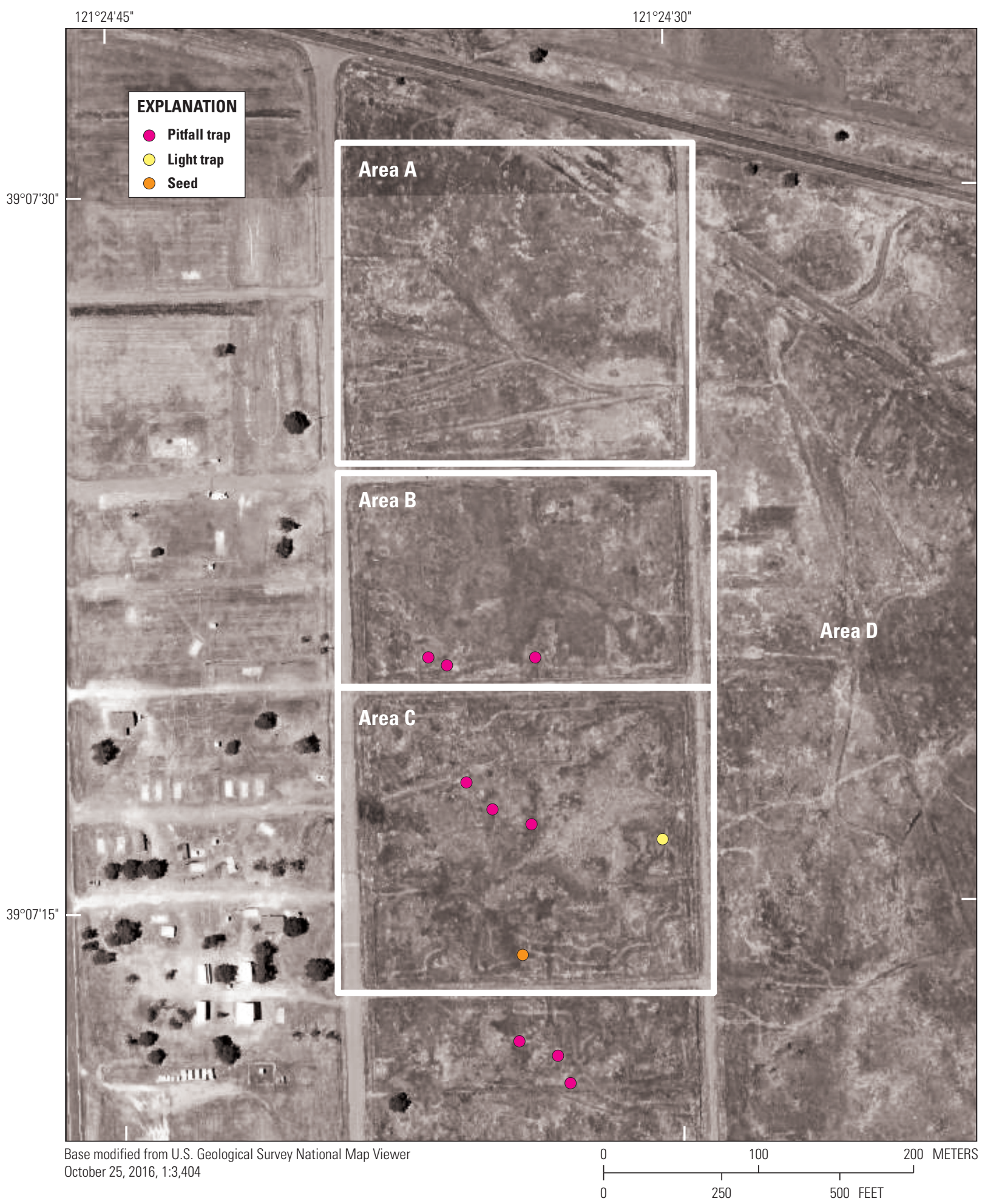

Figure 7. Location of sampling sites in the assessment areas of Beale Air Force Base: $A, \mathrm{DP} 038, B, \mathrm{SR} 627$ and SR594a, and $C$, ML586, ML585, and XU643b. 


\section{B, SR627 and SR594a}

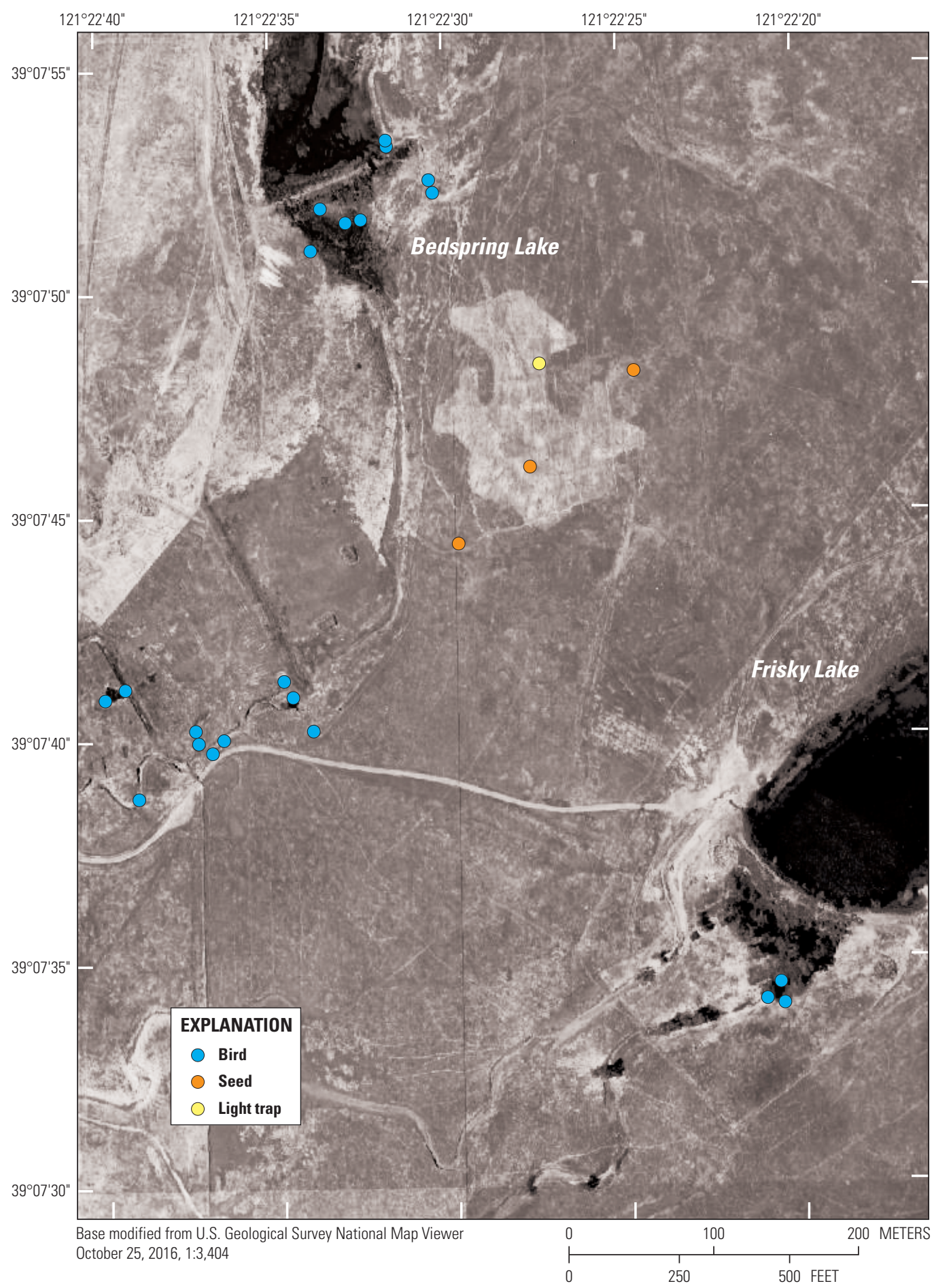

Figure 7. Location of sampling sites in the assessment areas of Beale Air Force Base: A, DP038, B, SR627 and SR594a, and C, ML586, ML585, and XU643b.-Continued 


\section{C, ML586, ML585, and XU643b}

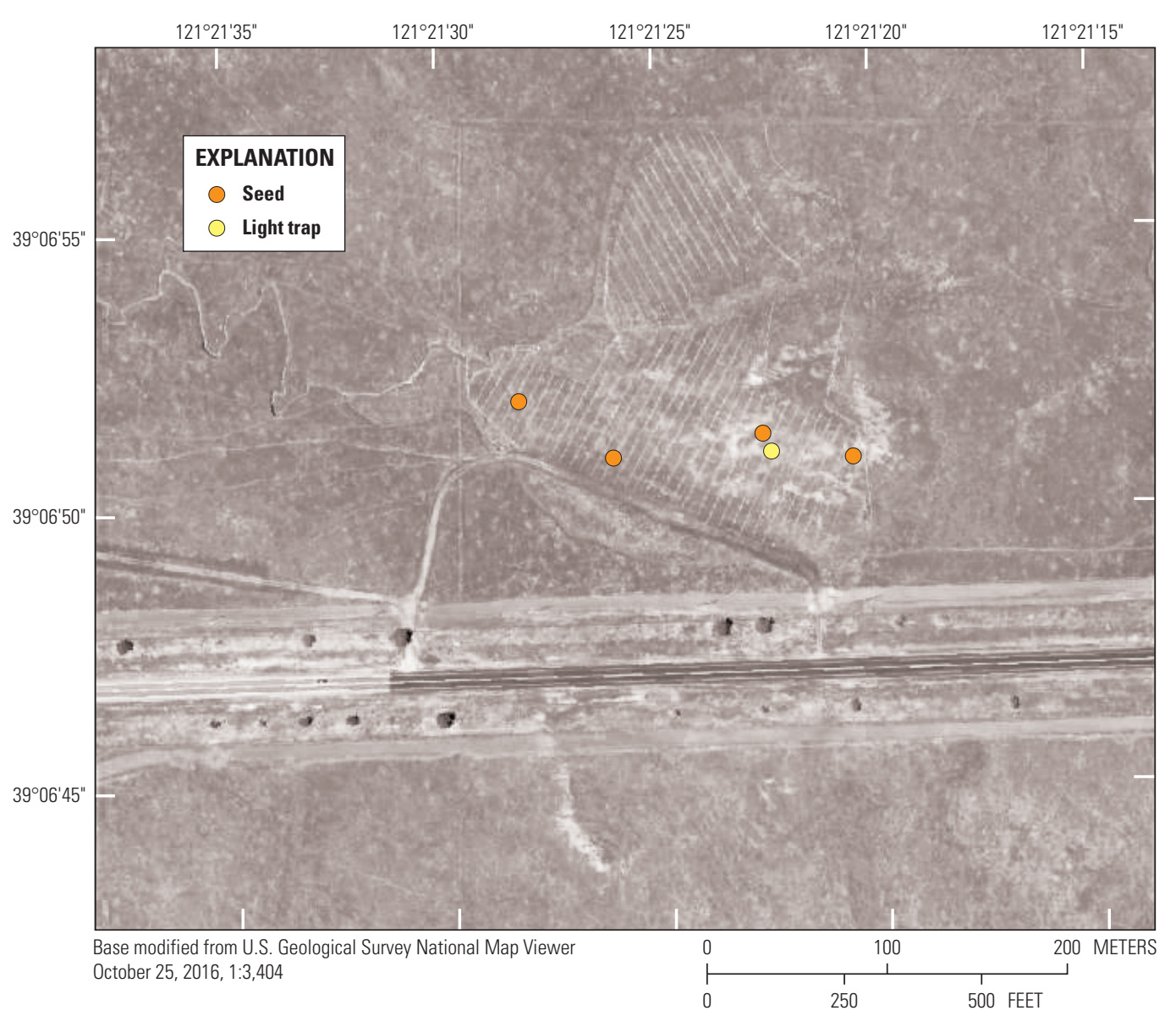

Figure 7. Location of sampling sites in the assessment areas of Beale Air Force Base: $A$, DP038, $B$, SR627 and SR594a, and C, ML586, ML585, and XU643b.-Continued 


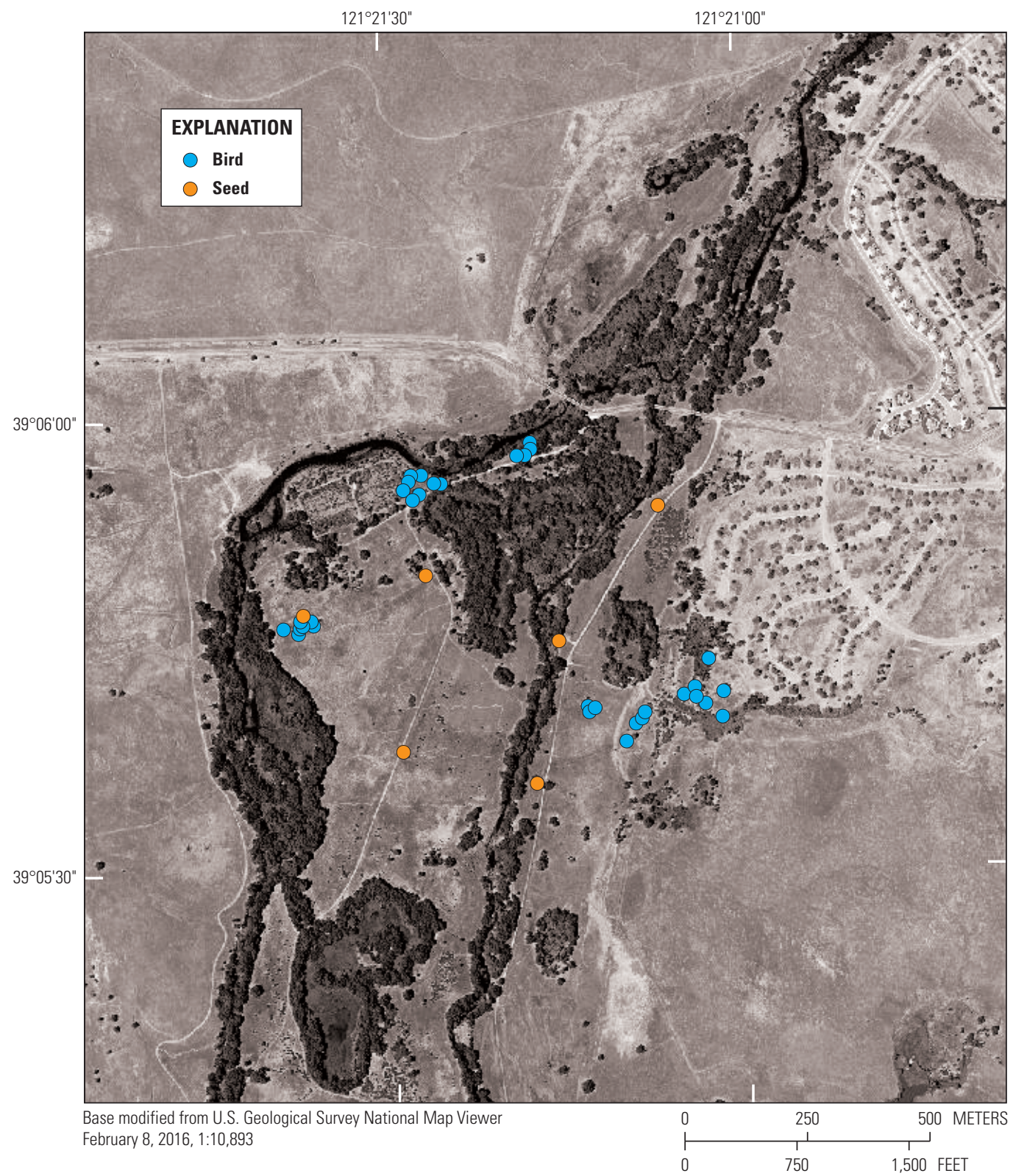

Figure 8. Locations of sampling sites in the reference areas of $A$, Beale Air Force Base, and $B$, St. Joe Bay Buffer Preserve for Tyndall Air Force Base. Pitfall and light trap locations not shown on this map. 


\section{B, St. Joe Bay Buffer Preserve}

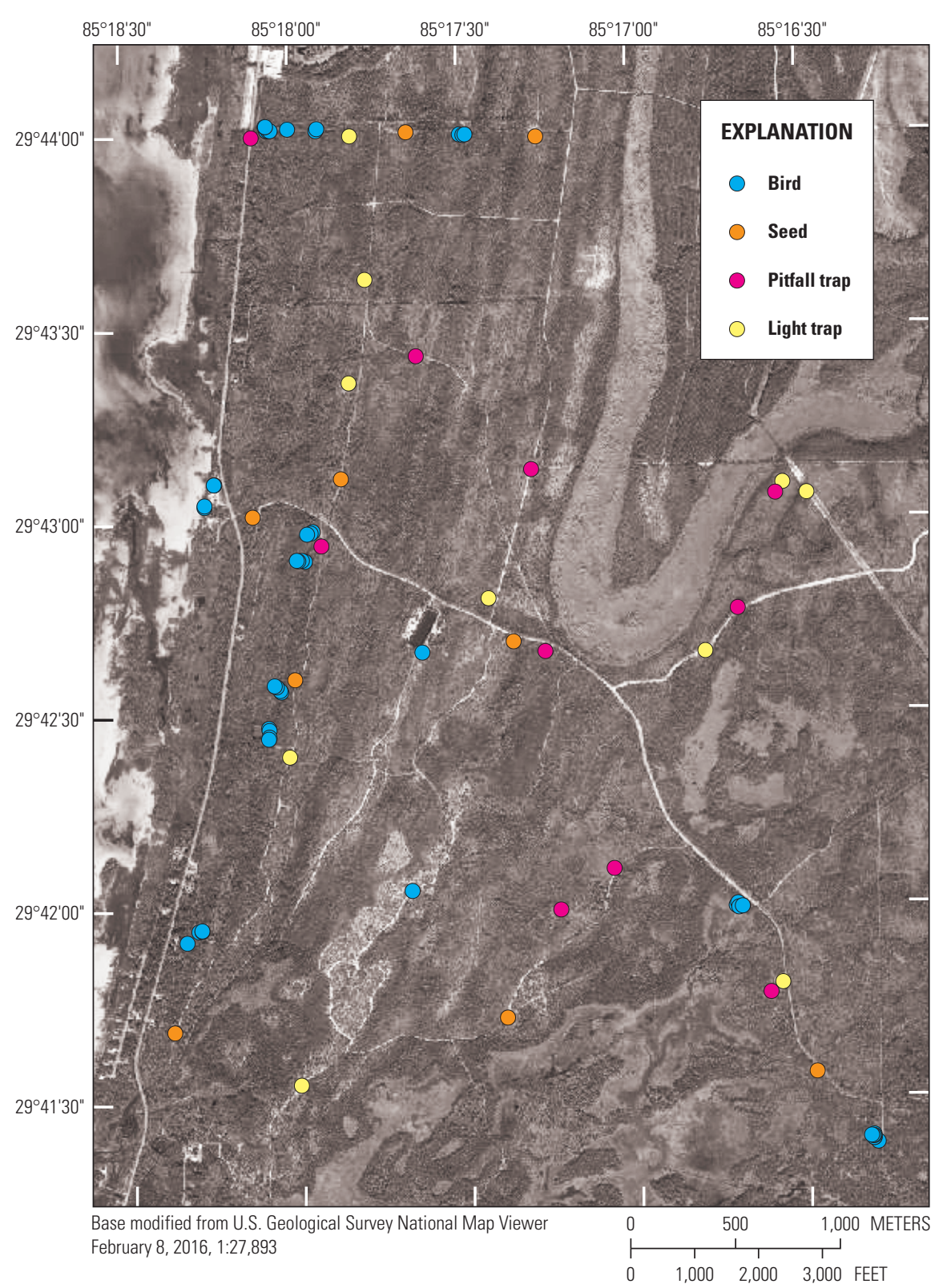

Figure 8. Locations of sampling sites in the reference areas of $A$, Beale Air Force Base, and $B$, St. Joe Bay Buffer Preserve for Tyndall Air Force Base.-Continued 
Table 2. Food ingestion rate, weight, and dietary composition of birds used in risk assessment.

[g/g bw day, gram per gram of body weight per day; g, gram; AFB, Air Force Base; --, no data; FIR, food ingestion rate]

\begin{tabular}{|c|c|c|c|c|c|c|c|}
\hline \multirow[t]{2}{*}{ Species } & \multirow[t]{2}{*}{ Latin name } & \multirow{2}{*}{$\begin{array}{c}\text { Applicable } \\
\text { Air Force } \\
\text { Base }\end{array}$} & \multirow{2}{*}{$\begin{array}{c}\text { Food } \\
\text { ingestion rate } \\
\text { (g/g bw day) }\end{array}$} & \multicolumn{2}{|c|}{$\begin{array}{l}\text { Weight } \\
\text { (g) }\end{array}$} & \multicolumn{2}{|c|}{$\begin{array}{l}\text { Dietary composition } \\
\text { (proportion) }\end{array}$} \\
\hline & & & & Minimum & Maximum & Invertebrates & Seeds \\
\hline Horned lark ${ }^{2}$ & Eremophila alpestris & Beale AFB & -- & 28 & 48 & 0.5 & 0.5 \\
\hline Western meadowlark ${ }^{2}$ & Sturnella neglecta & Beale AFB & -- & 89 & 115 & 0.5 & 0.5 \\
\hline Red-winged blackbird ${ }^{2}$ & Agelaius phoeniceus & Beale AFB & -- & 32 & 77 & 0.5 & 0.5 \\
\hline Canada goose ${ }^{3}$ & Branta canadensis & Beale AFB & 0.03 & 1,260 & 4,960 & 0 & 1 \\
\hline Northern cardinal ${ }^{2}$ & Cardinalis cardinalis & Tyndall AFB & -- & 42 & 48 & 0.5 & 0.5 \\
\hline Eastern towhee ${ }^{2}$ & Pipilo erythrophthalmus & Tyndall AFB & -- & 32 & 52 & 0.5 & 0.5 \\
\hline Mourning dove ${ }^{2}$ & Zenaida macroura & Tyndall AFB & -- & 86 & 156 & 0.01 & 0.99 \\
\hline
\end{tabular}

${ }^{1}$ Unless indicated in the source, the proportion for dietary composition was assumed to be 0.5 .

${ }^{2}$ Weights and dietary information from All About Birds (https://www.allaboutbirds.org/), Cornell Lab of Ornithology.

${ }^{3}$ Weights, dietary information, and FIR from U.S. Environmental Protection Agency (1993).

${ }^{4}$ Maximum reported FIR.

Equation 1 was the model used to estimate risk.

$$
\text { Risk }=\frac{F I R \times\left[\left(P_{\text {invert }} \times[P b]_{\text {invert }}\right)+\left(P_{\text {seeds }} \times[P b]_{\text {seeds }}\right)\right]+\left(P_{\text {soil }} \times[P b]_{\text {soil }}\right)}{\text { bird_ weight }(g)} \div T R V
$$

where

$$
\begin{aligned}
F I R & \text { is food ingestion rate; } \\
P_{\text {item }} & \text { is proportion of the diet composed of the dietary item (table 2); } \\
{[P b]_{\text {item }} } & \text { is Pb concentration in the dietary item; } \\
P_{\text {soil }} & \begin{array}{l}
\text { is proportion of diet composed of soils (incidental soil ingestion rate), which } \\
\text { based on information reported in Byer and others (1994) ranges from less }
\end{array} \\
& \quad \text { than 0.02 to 0.3; and } \\
T R V & \text { is toxicity reference value. }
\end{aligned}
$$

Risk is indicated by a unitless quotient of exposure and the TRV $\left(\frac{\text { exposure }}{T R V}\right)$. Risk is presumed when exposure exceeds the $T R V$, that is, when the quotient exceeds one.

The FIR was estimated using the following equations, which are from Nagy (1987) as cited in EPA (1993):

$$
\begin{gathered}
\text { FIR }(\text { passerine birds })=0.398 \times \text { bird_weight }(g)^{0.85} \\
\text { FIR }(\text { nonpasserine birds })=0.301 \times \text { bird_weight }(g)^{0.751}
\end{gathered}
$$

Food ingestion rates were derived for several passerine species commonly observed at Tyndall AFB (northern cardinal, Pipilo erythrophthalmus [rufous-sided towhee], mourning dove, and Thryothorus ludovicianus [Carolina wren]) and Beale AFB (Eremophilia alpestris [horned lark], Sutnella neglecta [western meadowlark], Agelaius phoeniceus [red-winged 
blackbird], and Passerculus sandwichensis [savanna sparrow]). Ingestion rates for two non-passerine species also were used for the risk assessment at Beale AFB because of the seasonal use of vernal wetlands by water fowl. However, because food ingestion rates for Branta canadensis (Canada goose) and Aythya affinis (lesser scaup) were available in the EPA handbook (EPA, 1993), they were used for risk estimation rather than an ingestion rate derived on the basis of the equations 2 and 3 .

On the basis of the "worst case scenario" assumptions, a risk quotient less than one would indicate risk is minimal, given what is known about exposure at the location and toxicity. However, if the risk quotient is equal to or greater than one, a probabilistic risk assessment was conducted.

The probabilistic risk assessment combined the range of possible exposures and toxic responses to give a better indication of risk likelihood. This was accomplished through Monte Carlo analysis, which repeatedly estimated exposure and selected toxicities to generate a set of risk quotients using the model described by equation 1 . Repeated exposure estimates were calculated or toxicities were selected when values for each of the variables in the risk model were randomly selected (Monte Carlo analysis) from distributions (for example, log normal, Weibull, beta) describing the datasets for $\mathrm{Pb}$ contamination, bird weight, proportion of dietary items in diet, and TRV. Given an adequate dataset $(n \geq 15)$, the best fit (Chisquare goodness-of-fit) of the data with statistical distributions (for example, log normal) was determined. If the dataset was insufficient, distributions were assumed. Distributions chosen for the variables are shown in table 3 . The distribution assumed (flat) for incidental soil ingestion is not shown in table 3 . The incidental ingestion rate (proportion of FIR mass) for birds was based on the range $(<0.02-0.3)$ reported by Beyer and others (1994). The percentage of risk quotients in the set generated by Monte Carlo analysis that exceeds one indicates the risk likelihood given the potential exposures and toxicities.

Table 3. Variables for probabilistic risk assessment for different bird species.

[N, normal; --, no data; ppm, parts per million; AFB, Air Force Base; L, log normal; Gam, gamma; Tri, triangular. Common name, Latin name: horned lark, Ermophilia alpestris; western meadowlark, Sturnella neglecta; red-winged blackbird, Agelaius phoeniceus; savanna sparrow, Passerculus sandwichensis; lesser scaup, Aythya affinis; Canada goose, Branta canadensis; northern cardinal, Cardinalis cardinalis; rufous-sided towhee, Pipilo erythrophthalmus; mourning dove, Zenaida macroura; carolina wren, Thryothorus ludovicianus]

\begin{tabular}{|c|c|c|c|c|c|c|c|c|c|c|c|c|c|c|c|c|c|c|}
\hline \multicolumn{9}{|c|}{ Bird mass } & \multicolumn{10}{|c|}{ Dietary proportion } \\
\hline \multicolumn{9}{|c|}{ Distribution type } & \multicolumn{10}{|c|}{ Distribution type } \\
\hline \multicolumn{9}{|c|}{ Triangular } & $\mathrm{N}$ & $\mathrm{N}$ & $\mathrm{N}$ & $\mathrm{N}$ & $\mathrm{N}$ & -- & $\mathrm{N}$ & $\mathrm{N}$ & Beta & Tri \\
\hline \multirow{3}{*}{ 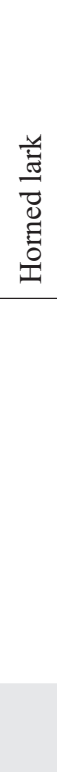 } & & & \multicolumn{16}{|c|}{ Lead concentrations (ppm dry weight) } \\
\hline & & & \multicolumn{6}{|c|}{ D-Street } & \multicolumn{3}{|c|}{ Frisky Lake } & \multicolumn{3}{|c|}{ Beale reference } & \multicolumn{4}{|c|}{ Tyndall AFB } \\
\hline & & Average $^{1}$ & 4.77 & 0.05 & 101.6 & 136.7 & 112.5 & 20.6 & 62.7 & 0.14 & -- & 13.2 & 0.06 & 6. & & 16.9 & 2.1 & 254.6 \\
\hline \multicolumn{3}{|c|}{ Standard deviation ${ }^{1}$} & 8.22 & 0.03 & 160.2 & 185.63 & 166.7 & 17.36 & 49.1 & 0.02 & -- & 22 & 0.03 & 2. & & 35.58 & 5.54 & 552.79 \\
\hline & istribu & tion type & $\mathrm{L}$ & $\mathrm{L}$ & Gam & Gam & $\mathrm{L}$ & $\mathrm{L}$ & $\mathrm{L}$ & $\mathrm{L}$ & -- & $\mathrm{L}$ & $\mathrm{L}$ & $\mathrm{L}$ & & $\mathrm{L}$ & $\mathrm{L}$ & $\mathrm{L}$ \\
\hline
\end{tabular}

${ }^{1}$ Average and standard deviations for the respective distributions were based on collected data. 


\section{Results-Beale Air Force Base}

All data discussed in this report are available in the companion data release (Bargar, 2019).

\section{Dietary Items}

Light traps were deployed at all suspect and reference areas. Qualitatively, the largest biomass of invertebrates captured by the light traps was at Frisky Lake, whereas the lowest biomass was collected by light traps at Warren Shingle Road. Pitfall traps were deployed only at D-Street and in the reference areas; the hard soils at Frisky Lake and Warren Shingle prevented deployment of pitfall traps at those areas.

Lead concentrations in invertebrates differed significantly among the suspect and reference areas (fig. 9). The lowest $\mathrm{Pb}$ concentrations in invertebrates were in those captured in the suspect area adjacent to Warren Shingle Road, whereas the highest concentrations in invertebrates were in those captured in the suspect area near Frisky Lake. No significant difference in $\mathrm{Pb}$ concentrations was evident between $\mathrm{D}$-Street and the reference area invertebrates. Although significant differences in $\mathrm{Pb}$ concentrations among the suspect and reference areas were determined for seeds, the nonparametric analysis could not make pair-wise comparisons among locations (fig. 9).

\section{Birds}

A total of 52 birds were collected in September 2016 from locations near Frisky Lake, an area potentially affected by $\mathrm{Pb}$. No birds were captured from $\mathrm{D}$-Street or from Warren
Shingle Road. A total of 19 birds were captured from the reference area in June 2017. The list of the birds captured is shown in table 4. None of the species found in the suspect areas were captured at the reference area.

$\mathrm{Pb}$ concentrations in the blood and feathers of the captured birds, and the $\delta$-ALAD activity in blood, are shown in figures 10,11 , and 12 , respectively. The average $\mathrm{Pb}$ concentrations in blood $(0.19 \mu \mathrm{g} / \mathrm{dL}$, standard error $(\mathrm{SE})=0.034)$ and feathers $(0.47 \mathrm{ppm} \mathrm{dw}, 0.115)$ for birds from the reference area were lower than concentrations in blood $(0.55 \mu \mathrm{g} / \mathrm{dL}, 0.071)$ and feathers $(0.60 \mu \mathrm{g} / \mathrm{dL}, 0.056)$ for birds from the suspect areas. The $\delta$-ALAD activity for birds from the reference area (42.9 nanomoles [nM] of aminolevulinic acid [ALA] per minute [min] per milliliter [ $\mathrm{mL}]$ of red blood cells [RBC], $\mathrm{SE}=4.06)$ was significantly greater $(\mathrm{p}<0.001)$ than for birds from the suspect area $(30.1 \mathrm{nM} / \mathrm{ALA} / \mathrm{min} / \mathrm{mL}$ of $\mathrm{RBC}, 1.09)$.

Inspection of the radiographs for captured birds found no evidence of $\mathrm{Pb}$ particles. Many of the images revealed highdensity areas, but comparison with reference $\mathrm{Pb}$ pellets within each image indicated those areas were unlikely to be $\mathrm{Pb}$ pellets or fragments.

\section{Risk Assessment}

Lead concentrations in blood were less than the level representative of background $\mathrm{Pb}$ contamination $(20 \mu \mathrm{g} / \mathrm{dL}$; Franson and Pain, 2011; fig. 13), and concentrations in feathers were less than the concentration associated with decreased nestling survival and effects on avian behavior and physiology (4 ppm dry weight; Tsipoura and others, 2011; fig. 14). A portion of the soils in all areas (A, B, C, and D) of D-Street exceeded the EPA (2005) Eco-SSL for risk to
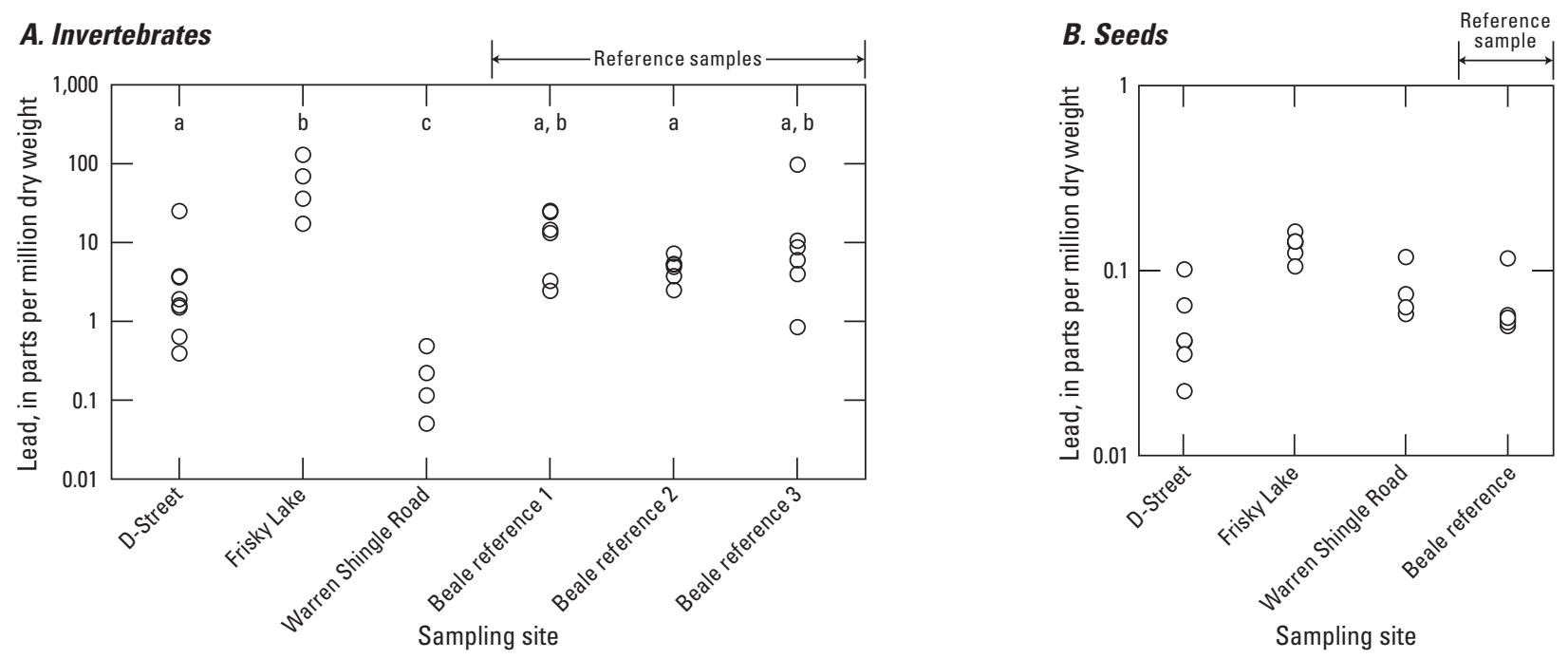

Figure 9. Lead concentrations in dietary items collected at Beale Air Force Base and its reference area: $A$, invertebrates and $B$, seeds. Letters above sampling sites in $A$ indicate whether lead concentrations for invertebrates from that site are the same (same letter) or significantly different (different letter) $(\alpha=0.05)$ relative to the other sites. Kruskal Wallis analysis of seed data in $B$ indicates lead concentrations are significantly different among areas $(\alpha=0.05)$. 
Table 4. Birds captured at Beale Air Force Base and the reference area, California.

\begin{tabular}{llc}
\hline \multicolumn{1}{c}{ Species } & \multicolumn{1}{c}{ Latin name } & $\begin{array}{c}\text { Number } \\
\text { captured }\end{array}$ \\
\hline Beale Air Force Base & \\
\hline Savanna sparrow & Passerculus sandwichensis & 22 \\
\hline Song sparrow & Melospiza melodia & 7 \\
\hline Grasshopper sparrow & Ammodramus savannarum & 1 \\
\hline White-crowned sparrow & Zonotrichia leucophrys & 10 \\
\hline Vesper sparrow & Pooecetes gramineus & 1 \\
\hline Northern mockingbird & Mimus polyglottos & 2 \\
\hline Mourning dove & Zenaida macroura & 2 \\
\hline Black phoebe & Sayornis nigricans & 3 \\
\hline Western meadowlark & Sturnella neglecta & 1 \\
\hline Brewer's blackbird & Euphagus cyanocephalus & 3 \\
\hline & Reference area & 1 \\
\hline Brown-headed cowbird & Molothrus ater & 3 \\
\hline Red-winged blackbird & Agelaius phoeniceus & 1 \\
\hline Ash-throated flycatcher & Myiarchus cinerascens & 7 \\
\hline Nuttall's woodpecker & Dryobates nuttallii & 2 \\
\hline Hooded oriole & Icterus cucullatus & 1 \\
\hline Bullock's oriole & Icterus bullockii & 3 \\
\hline California scrub jay & Aphelocoma californica & 1 \\
\hline House finch & Haemorhous mexicanus & 1 \\
\hline & & \\
\hline
\end{tabular}

avian insectivores (11 ppm dw) and herbivores (46 ppm dw), whereas contamination for portions of the soils in Areas B, $\mathrm{C}$, and D exceeded the soil-screening level for risk to avian carnivores (510 ppm dw; fig. 15). Geometric means for $\mathrm{Pb}$ concentrations in the four areas $(\mathrm{A}=40.8, \mathrm{~B}=48.3, \mathrm{C}=44.8$, $\mathrm{D}=15.1$ in ppm $\mathrm{dw}$ ) exceeded the avian insectivore Eco-SSL, whereas the geometric mean for Area B also exceeded the avian herbivore Eco-SSL.

Risk quotients from the conservative risk assessment exceeded one for both effect categories for all species foraging at D-Street and in the reference area. They also exceeded one at Frisky Lake for both effect categories for all species, except the Canada Goose. No risk quotients exceeded one at Warren Shingle Road. Soil contamination by $\mathrm{Pb}$ was not incorporated within the conservative risk estimate for Frisky Lake or Warren Shingle Road. Sampling of dietary items from D-Street was not designed to enable risk assessment for Areas A through D individually.

Probabilistic risk was estimated for birds foraging at D-Street, Frisky Lake, and the reference areas (table 5). Overall, the likelihood of Category 1 effects (lowest observed adverse effects) was greater than the likelihood of Category 2 effects ( $\mathrm{Pb}$ toxicity to reproduction, growth, and survival), which reflects the differing effect-level concentrations for the two categories. The likelihood of risk was greater for birds foraging at Frisky Lake relative to D-Street and the reference area. Risk likelihood was lower for larger birds (scaup and goose) and for the largely herbivorous Canada goose. The additional risk from incidental soil ingestion was greater for birds foraging at D-Street relative to birds foraging at the reference area. Risk likelihood for birds at Frisky Lake did not include risk from incidental soil ingestion.

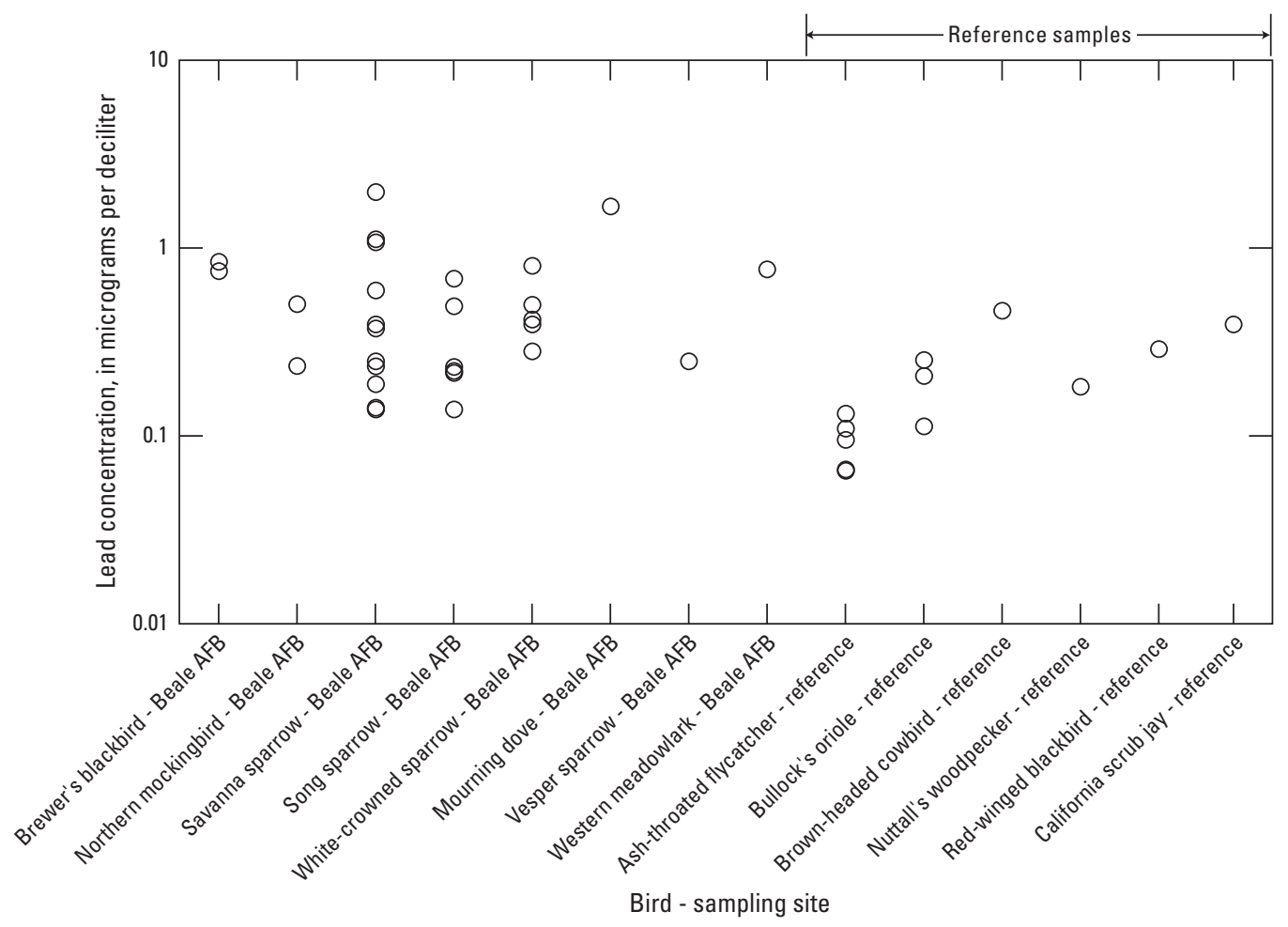

Figure 10. Lead concentrations in blood collected from birds captured at Beale Air Force Base (AFB), California, and its reference area. (See table 4 for Latin names of birds) 

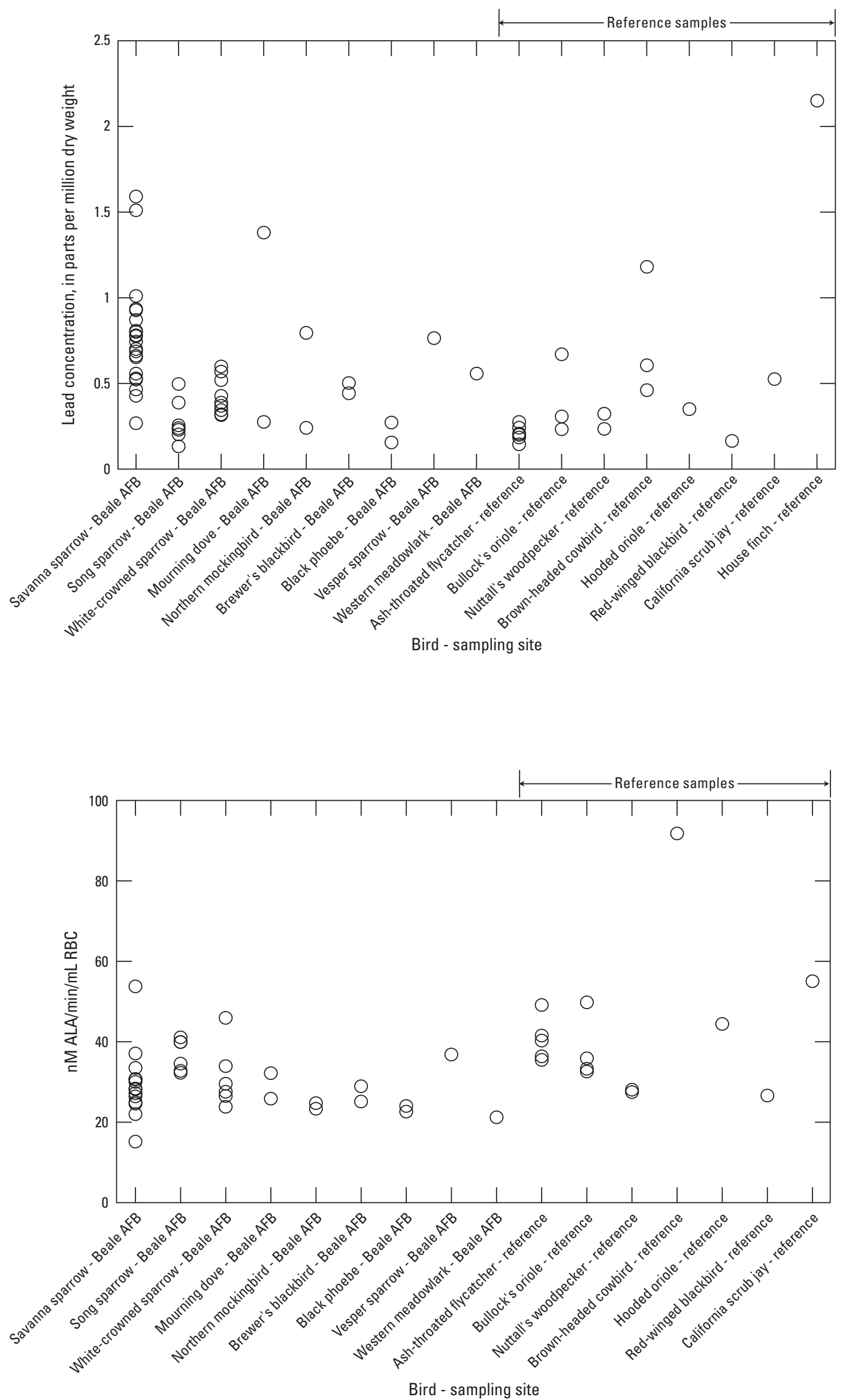

Figure 11. Lead concentrations in feathers collected from birds captured at Beale Air Force Base (AFB), California, and its reference area. (See table 4 for Latin names of birds)

Figure 12. $\delta$-aminolevulinic acid dehydratase activity (SALAD) in blood collected from birds captured at Beale Air Force Base (AFB), California, and its reference area. (nM ALA/ $\mathrm{min} / \mathrm{mL} \mathrm{RBC}$, nanomoles aminolevulinic acid per minute per milliliter of red blood cells; see table 4 for Latin names of birds) 


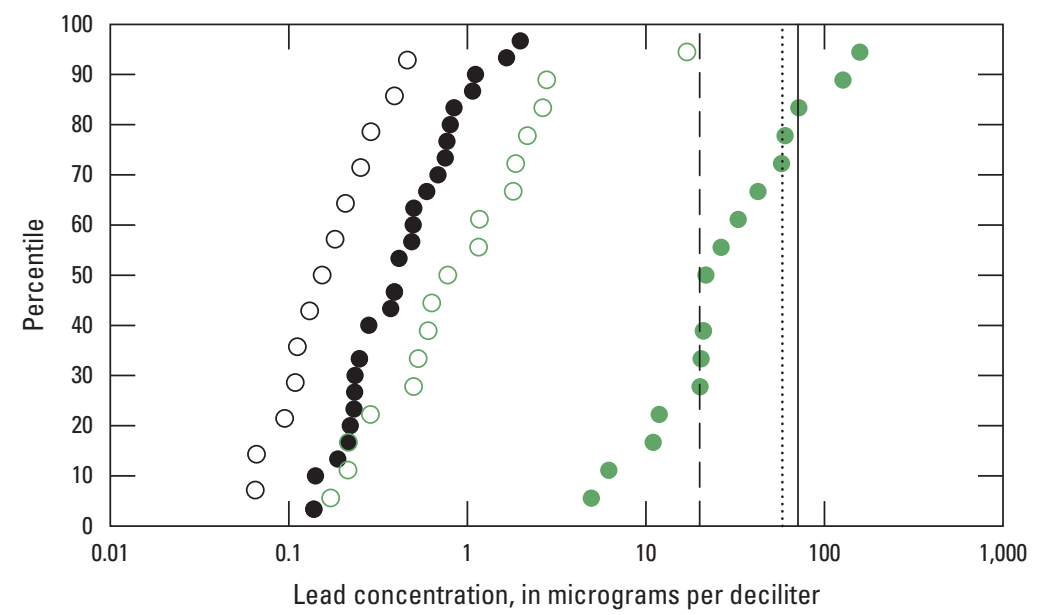

EXPLANATION

- - Background (Franson and Pain, 2011)

LOAEL (Johnson and others, 2007)

HC5 (Buekers and others, 2009)

Beale Air Force Base reference area

- Beale Air Force Base

St. Joe Bay Buffer Preserve

Tyndall Air Force Base

Figure 13. Lead concentrations in blood of birds captured at Beale Air Force Base (AFB) and its reference area, as well as for birds captured at Tyndall AFB and St. Joe Bay Buffer Preserve. The vertical lines show lead concentrations in blood considered to be background (20 micrograms per deciliter [ $\mu \mathrm{g} / \mathrm{dL}]$ ), the lowest observed adverse effect level (LOAEL; $58 \mu \mathrm{g} / \mathrm{dL}$ ), and the concentration affecting 5 percent of birds (HC5; $71 \mu \mathrm{g} / \mathrm{dL})$.

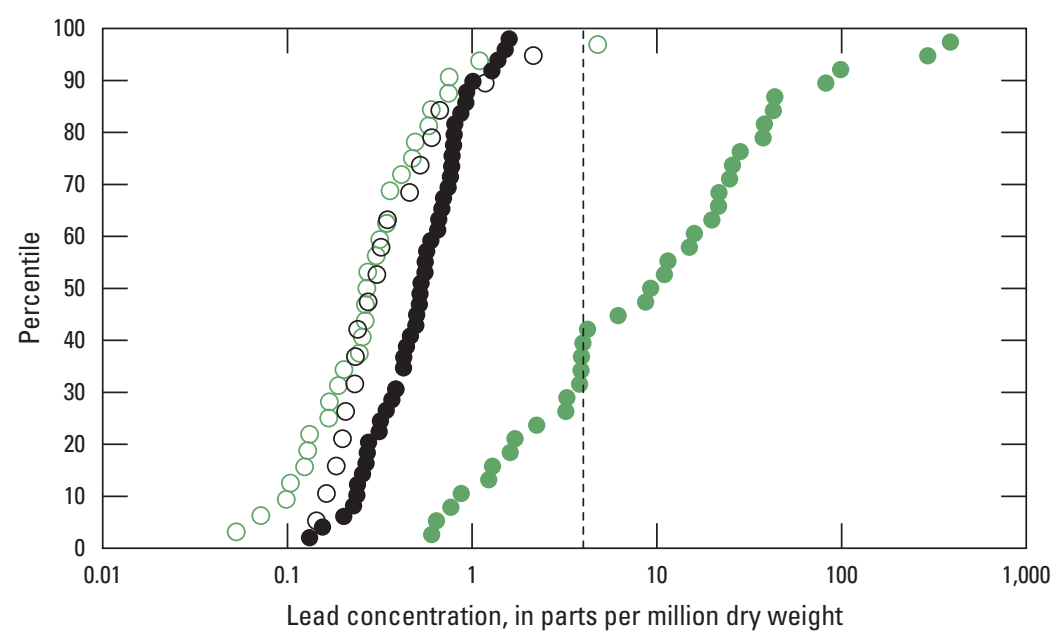

EXPLANATION

- - - - - Nestling survival, behavior, physiology

St. Joe Bay Buffer Preserve

$\bigcirc \quad$ Beale Air Force Base reference area

- Beale Air Force Base

- Tyndall Air Force Base

Figure 14. Lead concentrations in feathers of birds captured at Beale Air Force Base (AFB) and its reference area, as well as for birds captured at Tyndall AFB and its reference area, St. Joe Bay Buffer Preserve. The vertical line reflects the lead concentration (4 parts per million dry weight) associated with effects in nestling survival, and avian behavior and physiology (Tsipoura and others, 2011). 


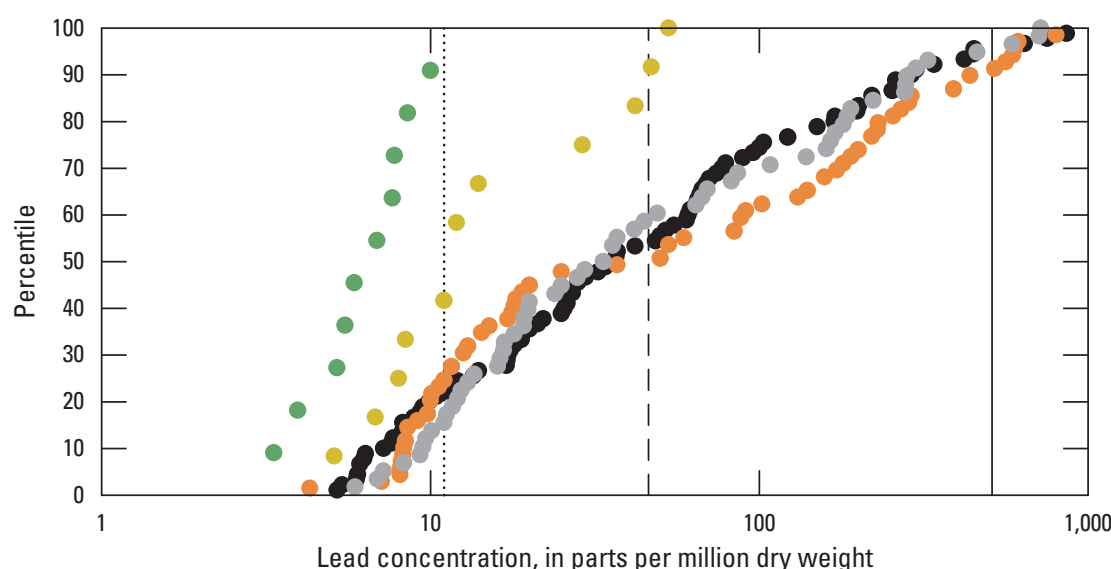

\section{EXPLANATION}

Ecological soil screening levels

.......... Insectivore

--- Herbivore

- Carnivore

Assessment areas

- D-Street area A

D-Street area B

D-Street area C

D-Street area D

Beale Air Force Base reference area

Figure 15. Lead concentrations in soils collected from the Beale Air Force Base reference area, California, and from areas A, $B, C$, and D of D-Street of Beale Air Force Base. Vertical lines represent the Ecological Soil Screening Levels for lead risk to avian insectivores (11 parts per million dry weight [ppm dw]), herbivores (46 ppm dw), and carnivores (510 ppm dw) (From EPA, 2005).

Table 5. Likelihood that daily exposure of birds to lead at D-Street and Frisky Lake at Beale Air Force Base, California, exceeds the lowest observed adverse effect level'.

[--, no data; shaded percentages indicate risk likelihood without the assumption of incidental soil ingestion]

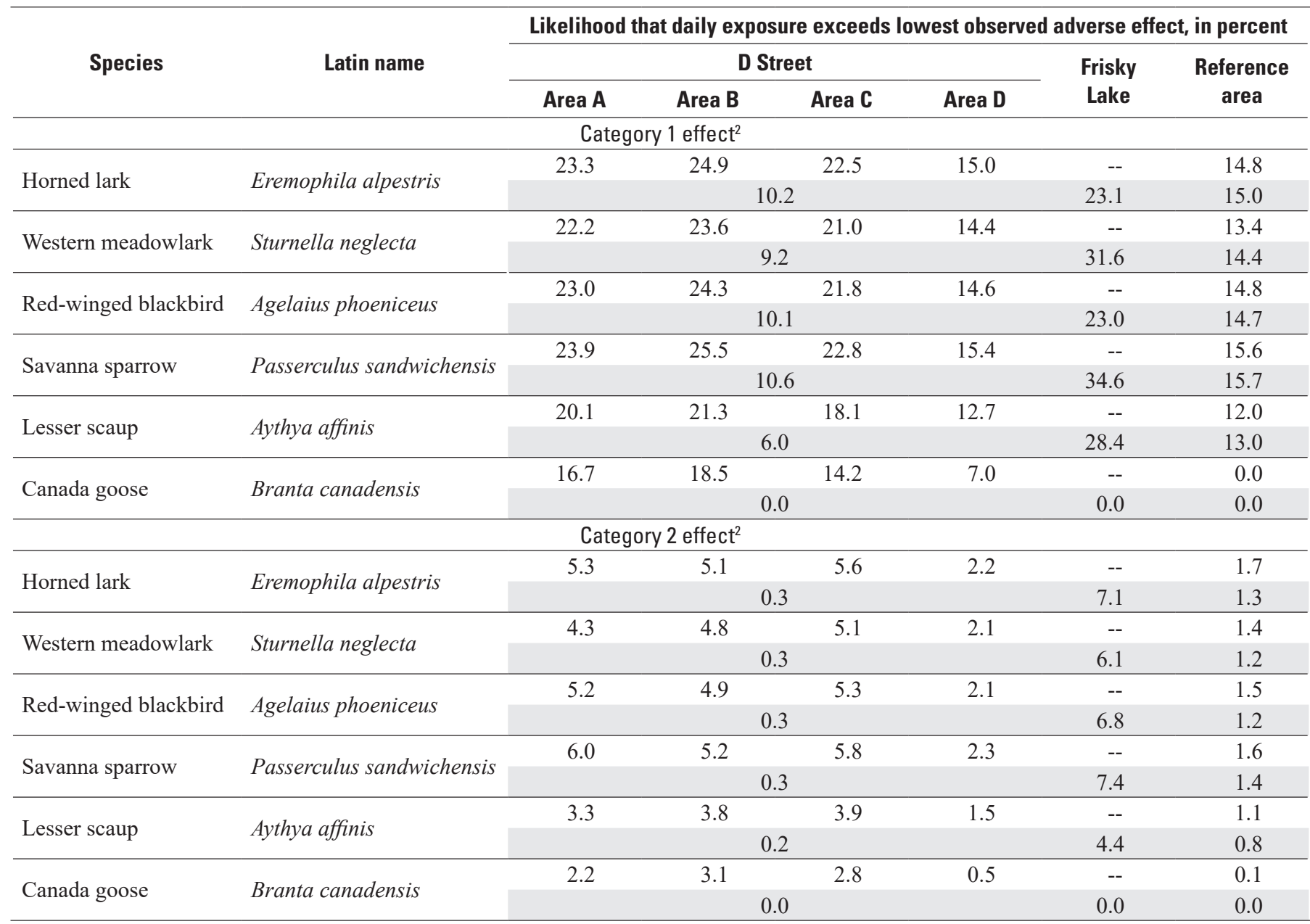

${ }^{1}$ Lowest-observed adverse effect levels as compiled in U.S. Environmental Protection Agency (2005).

${ }^{2}$ Category 1 effects are lead toxicity to blood biochemistry, physiology, pathology, and behavior; Category 2 effects are lead toxicity to reproduction, growth, and survival. 


\section{Results-Tyndall Air Force Base}

\section{Dietary Items}

Lead concentrations in invertebrates captured and seeds collected at Tyndall AFB were significantly greater $(\alpha=0.05)$ than in the same matrices from SJB (fig. 16). At Tyndall AFB, the average lead concentration was greater in invertebrates collected by the pitfall traps (geomean $=39.7 \mathrm{ppm} \mathrm{dw}$ ) than in those collected by the light traps (6.04 ppm dw). At SJB, on the other hand, $\mathrm{Pb}$ concentrations in invertebrates from pitfall traps $(1.11 \mathrm{ppm} \mathrm{dw})$ and light traps $(0.65 \mathrm{ppm} \mathrm{dw})$ approximated one another.

\section{Birds}

Seven different species were captured at Tyndall AFB during June and July 2016 and the 33 birds captured at SJB in August 2016 (table 6). Four species (northern cardinal, mourning dove, rufous-sided towhee, and Carolina wren) were captured at both Tyndall AFB and SJB.

Lead concentrations in blood and feathers were significantly greater $(\alpha=0.05)$ for northern cardinals and mourning doves captured at Tyndall AFB than for those from SJB (figs. 17 and 18). Accordingly, $\delta$-ALAD activity in blood was significantly lower $(\mathrm{p}<0.001)$ at Tyndall AFB $(18.3 \mathrm{nM}$ ALA/ $\mathrm{min} / \mathrm{mL} \mathrm{RBC}, \mathrm{SE}=3.26)$ relative to $\mathrm{SJB}(40.4 \mathrm{nM} \mathrm{ALA} / \mathrm{min} /$ $\mathrm{mL} \mathrm{RBC}, \mathrm{SE}=3.68$ ) (fig. 19).

tInspection of the radiographs of captured birds found no evidence of $\mathrm{Pb}$ particles. Many of the images revealed highdensity areas, but comparison with reference $\mathrm{Pb}$ pellets within each image indicated those areas were unlikely to be $\mathrm{Pb}$ pellets or fragments. Those high-density areas may have been grit within the digestive tract.
Table 6. Birds captured at Tyndall Air Force Base and St. Joe Bay Buffer Preserve, Florida.

\begin{tabular}{llc}
\hline \multicolumn{1}{c}{ Species } & \multicolumn{1}{c}{ Latin name } & $\begin{array}{c}\text { Number } \\
\text { captured }\end{array}$ \\
\hline & Tyndall Air Force Base & \\
\hline Northern cardinal & Cardinalis cardinalis & 16 \\
\hline Eastern towhee & Pipilo erythrophthalmus & 3 \\
\hline Mourning dove & Zenaida macroura & 14 \\
\hline Brown-headed cowbird & Molothrus ater & 3 \\
\hline Carolina wren & Thryothorus ludovicianus & 1 \\
\hline White-eyed vireo & Vireo griseus & 1 \\
\hline Brown thrasher & Toxostoma rufum & 2 \\
\hline & St. Joe Bay Buffer Preserve & 12 \\
\hline Northern cardinal & Cardinalis cardinalis & 10 \\
\hline Eastern towhee & Pipilo erythrophthalmus & 4 \\
\hline Mourning dove & Zenaida macroura & 12 \\
\hline Ovenbird & Seiurus aurocapilla & 1 \\
\hline Red-bellied woodpecker & Melanerpes carolinus & 2 \\
\hline Carolina wren & Thryothorus ludovicianus & 3 \\
\hline Red-winged blackbird & Agelaius phoeniceus & 14 \\
\hline
\end{tabular}

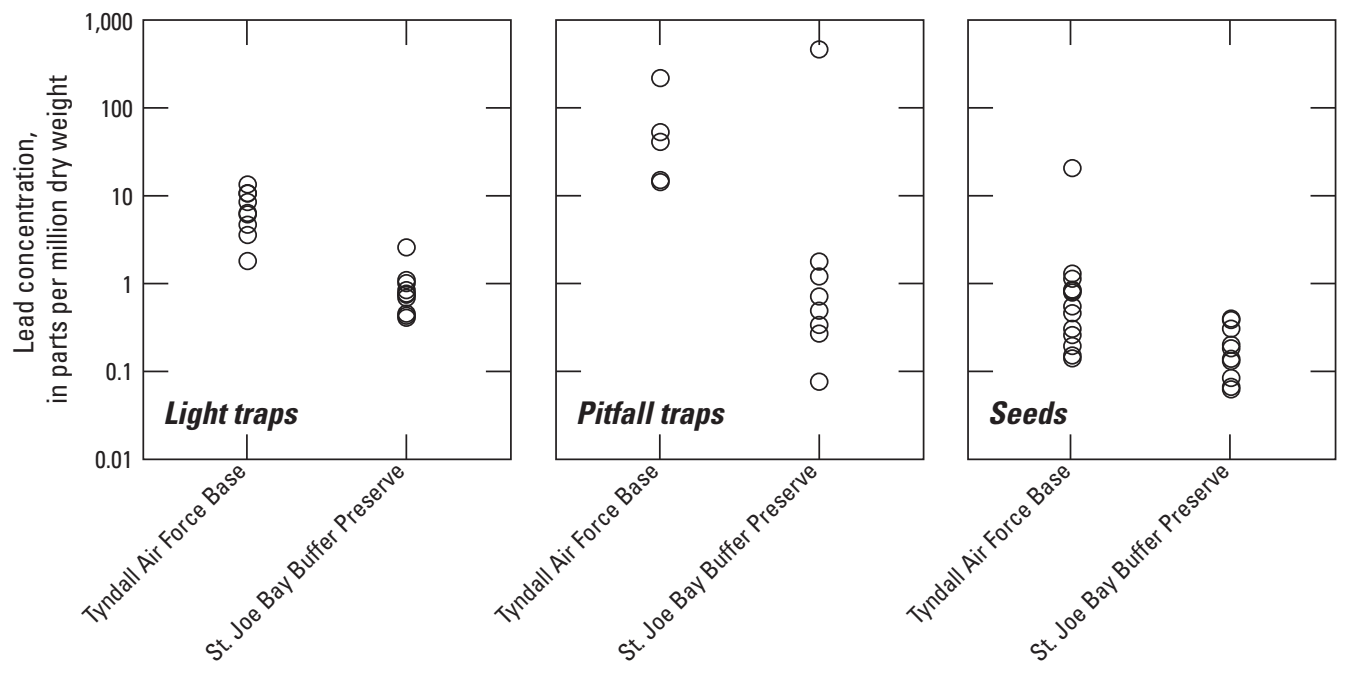

Figure 16. Lead concentrations in dietary items (invertebrates and seeds) collected from Tyndall Air Force Base and St. Joe Bay Buffer Preserve, Florida. Lead concentrations in seeds and invertebrates from Tyndall Air Force Base were significantly greater $(\alpha=0.05)$ than lead concentrations in invertebrates and seeds from St. Joe Bay Buffer Preserve. 


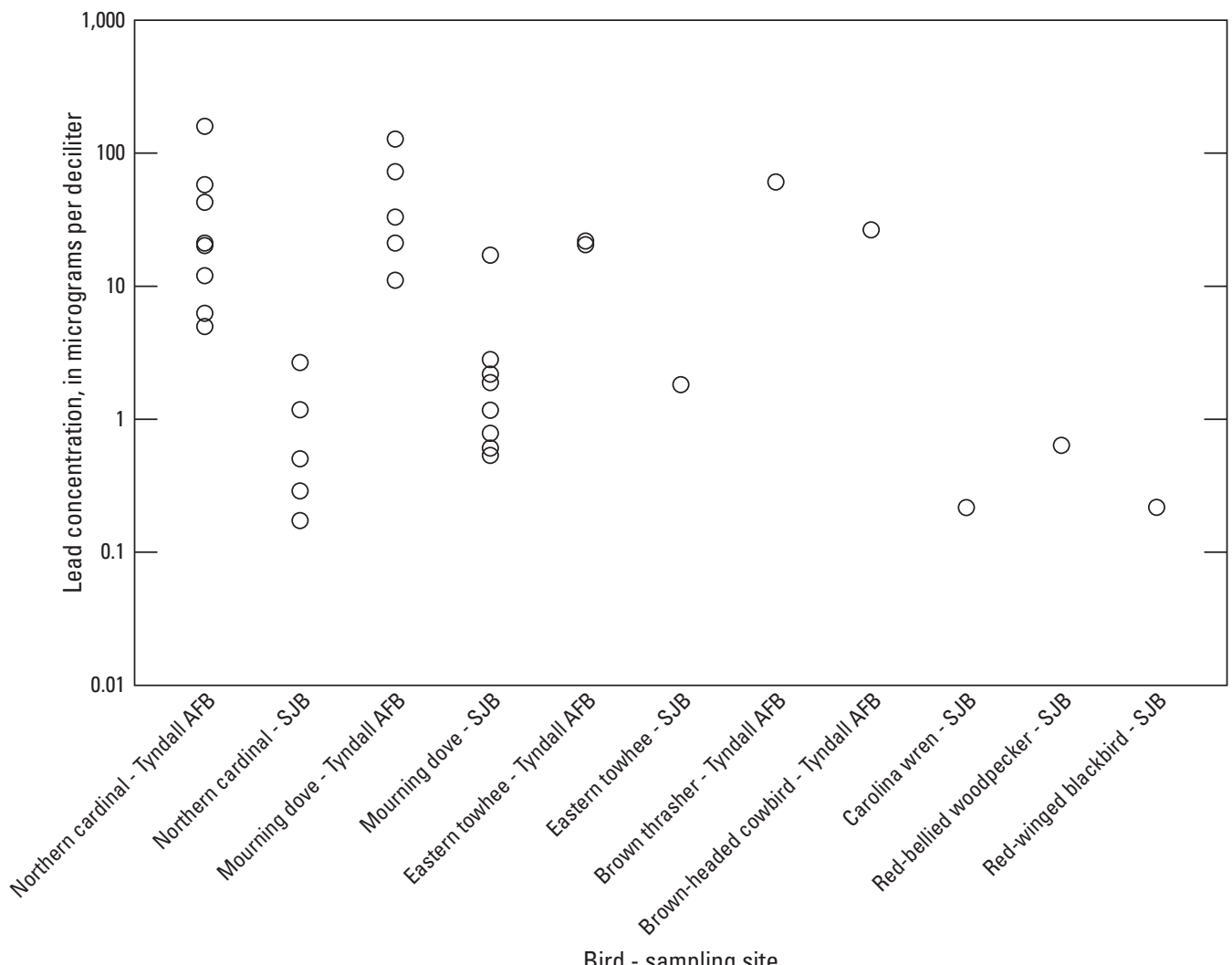

Bird - sampling site

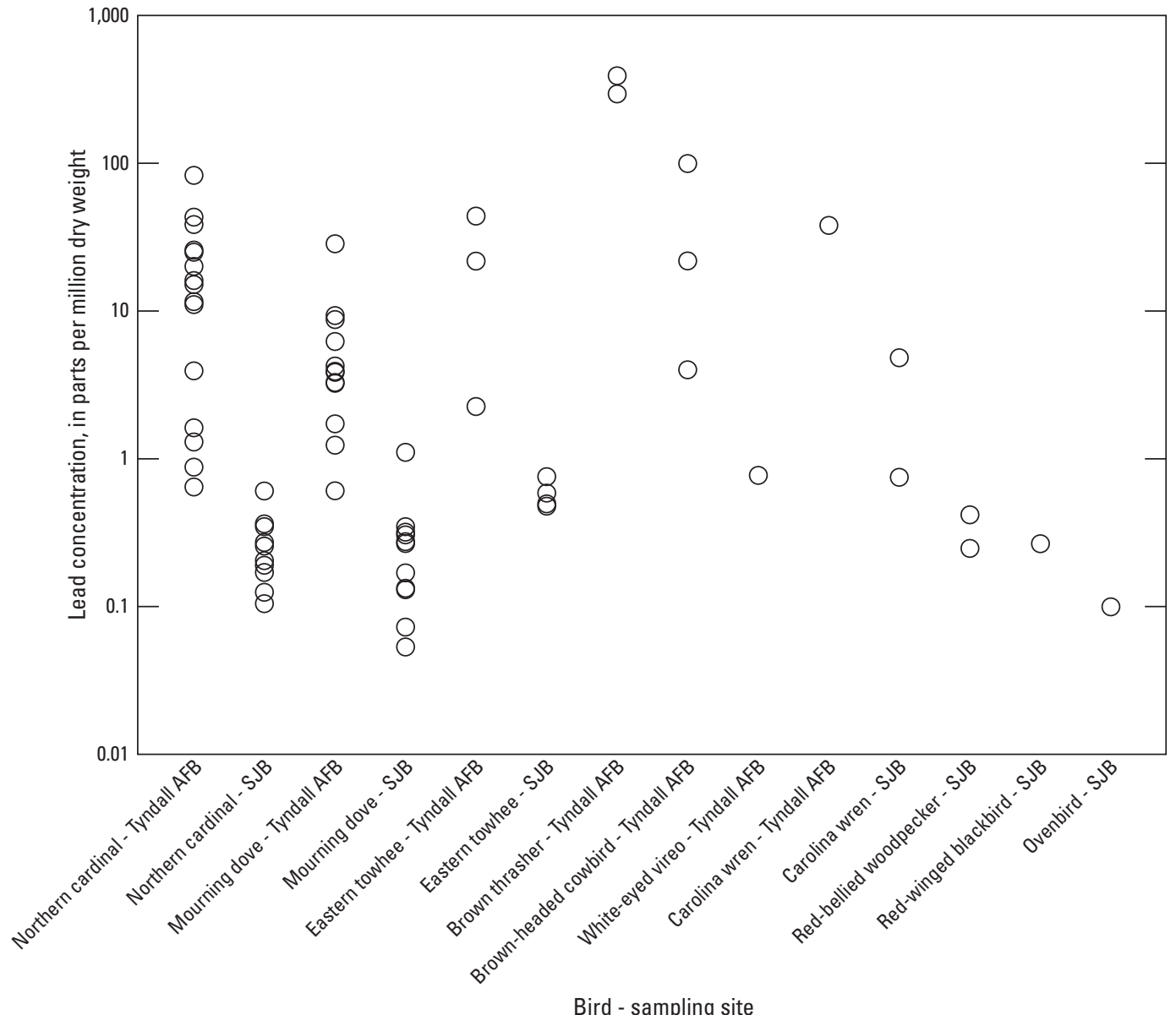

Bird - sampling site
Figure 17. Lead concentrations in blood collected from birds captured at Tyndall Air Force Base (AFB) and St. Joe Bay Buffer Preserve (SJB), Florida. Lead concentrations for northern cardinals and mourning doves were significantly greater $(\alpha=0.05)$ at Tyndall AFB than at SJB. (See table 6 for Latin names of birds)

Figure 18. Lead concentrations in feathers collected from birds captured at Tyndall Air Force Base (AFB) and St. Joe Bay Buffer Preserve (SJB), Florida. Lead concentrations for northern cardinals and mourning doves were significantly greater $(\alpha=0.05)$ at Tyndall AFB than at SJB. (See table 6 for Latin names of birds) 


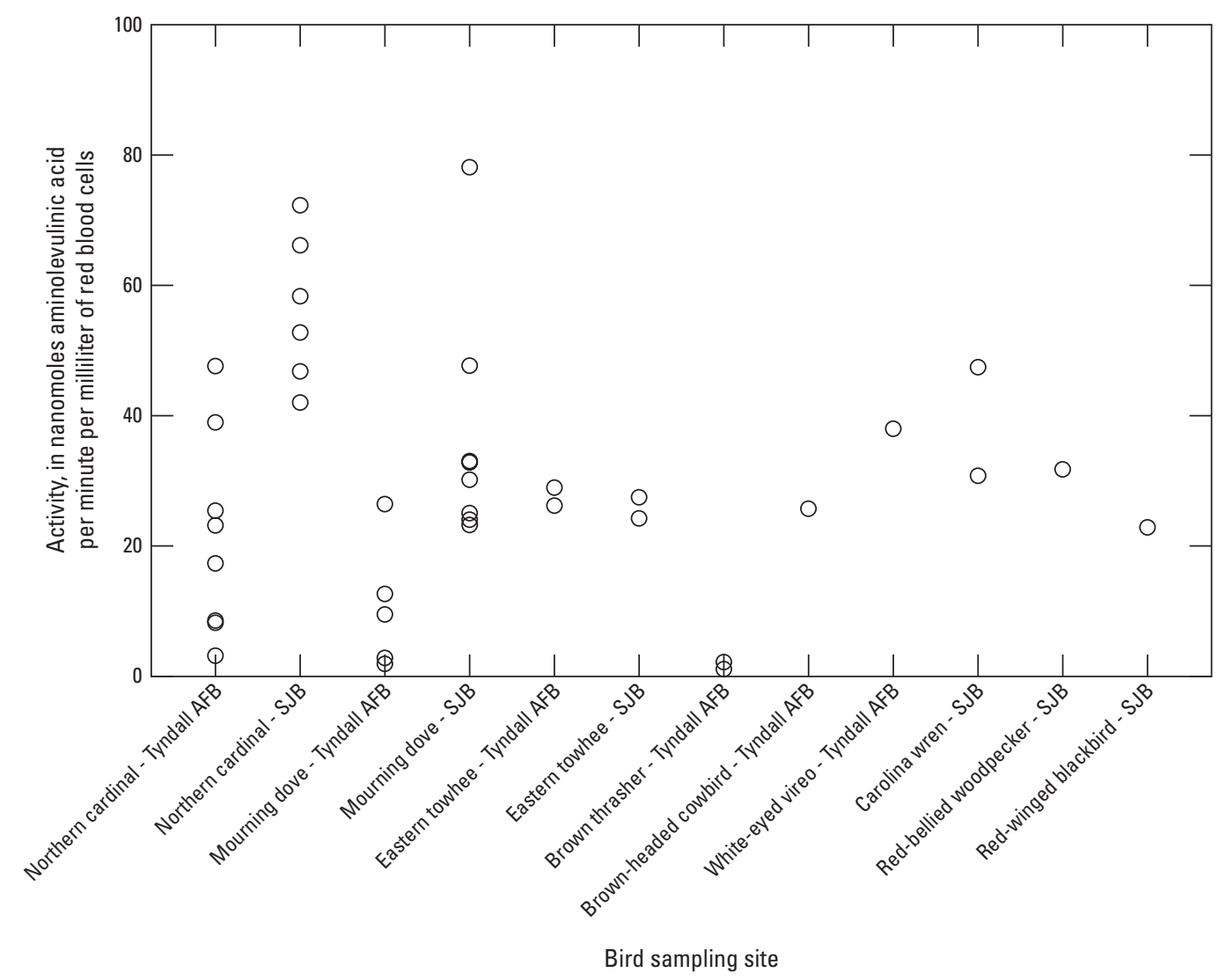

Figure 19. $\delta$-aminolevulinic acid dehytratase activity in blood collected from birds captured at Tyndall Air Force Base (AFB) and St. Joe Bay Buffer Preserve (SJB), Florida. Activity for northern cardinals and mourning doves was significantly lower $(\alpha=0.05)$ at Tyndall AFB than at SJB. (See table 6 for Latin names of birds)

\section{Risk Assessment}

Lead contamination in blood samples from approximately 20 percent of the birds captured at Tyndall AFB exceeded $58 \mu \mathrm{g} / \mathrm{dL}$, a contamination level suggested as the lowest observed adverse effect level for $\mathrm{Pb}$ effects in birds (Johnson and others, 2007) (fig. 13). Lead contamination in a similar proportion of birds exceeded $71 \mu \mathrm{g} / \mathrm{dL}$, a suggested HC5 for effects in birds (Buekers and others, 2009). Lead concentrations in approximately 60 percent of the feathers sampled from birds captured at Tyndall AFB exceeded the concentration associated with reduced nestling survival and adverse effects in physiology and behavior (4 ppm dw; Burger and Gochfeld, 2000; Tsipoura and others, 2011) (fig. 14). Except for Pb in feathers from one bird (Carolina wren), contamination in blood and feathers for birds from SJB did not exceed levels indicative of adverse effects.
Approximately 90 percent of the discrete soil samples from Tyndall AFB had $\mathrm{Pb}$ concentrations that exceeded the Eco-SSL for avian insectivores, 60 percent exceeded the EcoSSL for herbivorous birds, and 15 percent exceeded the EcoSSL for carnivorous birds (fig. 20). The geometric mean $\mathrm{Pb}$ concentration in Tyndall AFB soils (58.7 ppm dw) exceeded the Eco-SSL for insectivorous and herbivorous birds, but not the Eco-SSL for carnivorous birds. Lead concentrations in soils from SJB did not exceed any of the Eco-SSLs.

The assumption of maximal exposure for the most sensitive species at Tyndall AFB and SJB resulted in risk quotients greater than one. As a result, the likelihood of risk for birds at both areas was estimated (table 7). Risk likelihood was greater for birds foraging at Tyndall AFB than for birds foraging at SJB. 


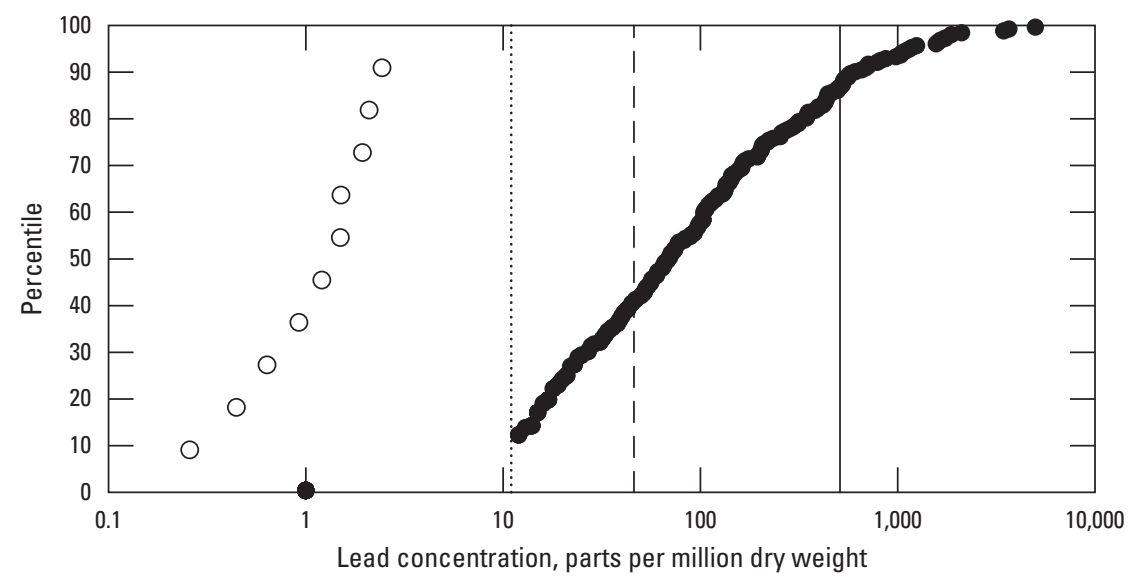

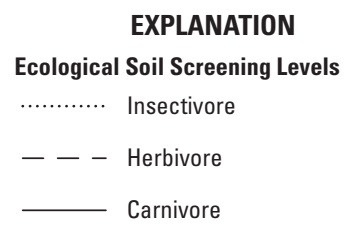

Assessment areas

O St. Joe Bay Buffer Preserve

- Tyndall Air Force Base

Figure 20. Lead concentrations in soils from Tyndall Air Force Base and St. Joe Bay Buffer Preserve, Florida. Vertical lines represent the Ecological Soil Screening Levels for insectivorous (11 parts per million dry weight [ppm dw]), herbivorous (46 ppm dw), and carnivorous (510 ppm dw) birds.

Table 7. Likelihood that daily exposure of birds to lead at Tyndall Air Force Base and St. Joe Bay Buffer Preserve, Florida, exceeds the lowest observed adverse effect level'.

\begin{tabular}{|c|c|c|c|c|c|c|c|c|c|}
\hline \multirow{4}{*}{ Species } & \multirow{4}{*}{ Latin name } & \multicolumn{8}{|c|}{$\begin{array}{l}\text { Likelihood that daily exposure to lead exceeds the lowest observed adverse } \\
\text { effect level, in percent }\end{array}$} \\
\hline & & \multicolumn{4}{|c|}{ Tyndall Air Force Base } & \multicolumn{4}{|c|}{ St. Joe Bay Buffer Preserve } \\
\hline & & \multicolumn{2}{|c|}{ Category 1} & \multicolumn{2}{|c|}{ Category 2} & \multicolumn{2}{|c|}{ Category 1} & \multicolumn{2}{|c|}{ Category 2} \\
\hline & & Soil & No soil ${ }^{2}$ & Soil & No soil ${ }^{2}$ & Soil & No soil ${ }^{2}$ & Soil & No soil ${ }^{2}$ \\
\hline Northern cardinal & Cardinalis cardinalis & 30.9 & 18.4 & 9.4 & 2.6 & 5.0 & 4.7 & 0.7 & 0.4 \\
\hline Eastern towhee & Pipilo erythrophthalmus & 30.9 & 18.5 & 9.5 & 2.7 & 5.0 & 4.7 & 0.6 & 0.4 \\
\hline Mourning dove & Zenaida macroura & 25.9 & 7.6 & 7.4 & 0.6 & 0.4 & 0.3 & 0.1 & 0.1 \\
\hline Carolina wren & Thryothorus ludovicianus & 34.0 & 22.4 & 11.1 & 4.1 & 7.5 & 6.9 & 1.2 & 0.7 \\
\hline
\end{tabular}

${ }^{1}$ Lowest observed adverse effect levels compiled by the U.S. Environmental Protection Agency (2005).

${ }^{2}$ Risk likelihood without assumed incidental soil ingestion. 


\section{Discussion}

\section{Beale Air Force Base}

The average $\mathrm{Pb}$ concentration in reference area soil $(6.5 \mathrm{mg} / \mathrm{kg})$ was lower than the average reported for soils in California (19.7 mg/kg; https://www.epa.gov/superfund/ usgs-background-soil-lead-survey-state-data), indicating that contamination in the reference area soils likely represents background levels. What is not clear, however, is $\mathrm{Pb}$ contamination in the suspect areas on a spatial scale larger than the remediated areas. The risk for birds estimated in this report assumes birds forage exclusively at locations with contamination levels represented by the present study. But it is expected that birds forage over a larger area, or multiple areas, where $\mathrm{Pb}$ contamination may differ from that assessed in the present study. If so, the actual risk for birds would differ from that predicted in the present study.

On the basis of the available information for $\mathrm{Pb}$ contamination in soils, average $\mathrm{Pb}$ concentrations in the dietary items did not parallel contamination in the soils. Despite D-Street soils being relatively contaminated by $\mathrm{Pb}$, concentrations in dietary items were not the highest. The highest contamination of dietary items was found at Frisky Lake. Because $\mathrm{Pb}$ concentrations in the borrow pit soils were low, many of the sampled invertebrates may have been drawn from nearby areas where the $\mathrm{Pb}$ concentrations are elevated. Given the slope of the terrain from SR627/SR594a (Frisky Lake) towards an adjacent intermittent stream and seasonal wetland, a portion of the past and current $\mathrm{Pb}$ contamination may have been transported to the wetland area. Light traps at Frisky Lake drew the largest mass of invertebrates relative to traps elsewhere on Beale AFB, Beale reference area, Tyndall AFB, and SJB. Given the dry, uniform habitat elsewhere around the location where the traps were placed at Frisky Lake, the greater biomass likely was due to elevated productivity at the adjacent wetland and indicates that the wetland was also the source of the elevated $\mathrm{Pb}$ concentrations.

Lead contamination and $\delta$-ALAD activity in the captured birds allude to potential differences in $\mathrm{Pb}$ availability between the reference and suspect areas. Lead concentrations in blood and feathers were greater, and $\delta$-ALAD activity was lower, for birds from the suspect area. However, there is uncertainty in the interpretation of these differences. First, no single species was captured from the reference area and from the suspect area. Variation among species of dietary preferences (Moorman and others, 2007; EPA, 1993) and physiology could confound interpretation of any locational contribution to the contamination and enzyme activity levels. Most of the species captured in the suspect area (sparrows) in September were possible migrants that were not observed in the suspect or reference areas in June when reference area was sampled. Second, birds captured from the suspect areas were primarily from Bedspring Lake (fig. 3), which is part of the wetland area adjacent to Frisky Lake. The availability of $\mathrm{Pb}$ to birds foraging at D-Street and Warren Shingle Road is not clear from the present study.

The risk likelihood estimated for birds at Beale AFB and the reference area varied. Generally, the highest risk was estimated for Frisky Lake and the lowest for the reference area, a pattern that paralleled $\mathrm{Pb}$ concentrations in invertebrates. The contribution to risk from contamination in the invertebrates was also evident from the lack of risk for the Canada goose, for which the assumed dietary preference was 100 percent seeds (EPA, 1993). Risk would be minimal for birds that consumed primarily seeds and greater for birds that consumed a greater proportion of invertebrates. Given the significance of dietary preference to the estimated risk, the lack of knowledge about the true dietary composition for a focal bird species is a significant uncertainty in this risk assessment. Other than for the Canada goose, this risk assessment assumed the dietary preference of birds for invertebrates and seeds varied normally with a central tendency of 50 percent. In addition, the proportion of invertebrates and seeds consumed by the birds was assumed to vary inversely; as the proportion of one increased, the proportion for the other decreased. Under these assumptions, risk likelihood would increase as the dietary proportion made up of invertebrates increased. For several of the species for which risk was estimated (for example, western meadowlark, red-winged blackbird), the proportion of the diet made up of invertebrates was greater during the late spring and summer (that is, nesting season) than in the fall and winter (https:// www.allaboutbirds.org), indicating possible seasonal variation of risk. Another significant uncertainty in the risk assessment is the true level of incidental soil ingestion. Lead exposure owing to incidental soil ingestion resulted in greater than 50 percent of the risk for birds (100 percent for the Canada goose) at the D-Street location and accounted for practically all the risk for Category 2 effects at D-Street. The contribution of soil ingestion to risk at Frisky Lake was not determined owing to the lack of data on overall soil $\mathrm{Pb}$ contamination. Beyer and others (1994) reported incidental soil ingestion rates for birds ranging from less than 2 to 30 percent of diet, which served as the basis for the risk estimates in the present study. Because most of those data were for ducks and sandpipers (none for passerine birds), the level of incidental soil ingestion for passerine birds and its contribution to the risk is unknown.

Greater risk likelihood was estimated for Category 1 effects than for Category 2 effects. Category 1 includes effects on behavior, physiology, and biochemistry, whereas Category 2 includes effects on survival, reproduction, and growth. Therefore, there is a greater likelihood of changes in behavior, physiology, or biochemistry than in reproduction, growth, or survival. The reduction of $\delta$-ALAD activity in what were apparently healthy birds supports this risk estimate. The Category 1 endpoints are generally more sensitive to toxicant exposure relative to effects in Category 2, which would explain the greater risk likelihood. However, the significance to populations or ecosystems of effects in Category 1 relative to Category 2 has been debated by regulators and by scientists 
in the open literature. Organisms have a normal range of physiological activity that often is inadequately characterized prior to their measurement in environmental assessments, and they have compensatory mechanisms that allow them to survive, grow, or reproduce despite alterations of the Category 1 endpoints (Hagger and others, 2006).

In summary, $\mathrm{Pb}$ contamination of dietary items at Beale AFB was sufficient to result in estimated risk likelihoods for birds of up to 35 percent. The risk likelihood was proportional to the consumption of invertebrates and incidental soil ingestion where $\mathrm{Pb}$ concentrations in soil are elevated. The paradox of low $\mathrm{Pb}$ concentrations in dietary items at D-Street despite elevated $\mathrm{Pb}$ concentrations in co-located soils ideally would be investigated further to reduce uncertainty in the risk estimation for that location. Lastly, the source of the greater $\mathrm{Pb}$ concentrations in invertebrates from Frisky Lake, which led to the elevated risk likelihood, also could be investigated.

\section{Tyndall Air Force Base}

Lead contamination was greater at Tyndall AFB than at SJB. Differences were evident for invertebrates, seeds, and soil, and for blood and feathers of bird species captured at the $\mathrm{AFB}$ and $\mathrm{SJB}$. At the AFB, it is unknown why $\mathrm{Pb}$ concentrations in the invertebrates captured by the pitfall traps were greater than the concentrations in the invertebrates captured by the light traps. Although the internal $\mathrm{Pb}$ concentrations could be greater for invertebrates collected in the pitfall traps, some of the invertebrate species were captured by both the pitfall and light traps, indicating the that measured concentrations were not strictly internal. In addition, the analytical laboratory did not process the invertebrates to remove potential external contamination. Therefore, it is likely that the invertebrates captured by the pitfall traps were externally contaminated by soil-associated particles. Regardless, birds consuming soilassociated invertebrates will be incidentally ingesting soil particles and the associated $\mathrm{Pb}$.

The elevated $\mathrm{Pb}$ concentrations at the AFB increased the exposure of birds to $\mathrm{Pb}$ and is likely adversely affecting birds. For the northern cardinal and mourning dove, $\mathrm{Pb}$ concentrations in blood and feathers were significantly greater at the Tyndall AFB than at SJB. Lead concentrations in blood and feathers of the rufous-sided towhee also were greater at Tyndall AFB, but the statistical significance of the difference was not evaluated because too few birds were captured at both locations. The elevated exposures to $\mathrm{Pb}$ paralleled significant depression of $\delta$-ALAD activity for birds from the AFB relative to the same species at SJB. In fact, no activity was measured in the blood of a few birds captured at the AFB (northern cardinal, mourning dove, Toxostoma rufum [brown thrasher]).

Foraging behavior, in addition to dietary preference, likely plays a significant role in risk for birds on the AFB. Greater risk would be expected for invertivorous birds than for to granivorous birds, given the greater $\mathrm{Pb}$ concentrations in invertebrates relative to seeds. The northern cardinal feeds predominantly on seeds and fruit but also consumes invertebrates (Halkin and Linville, 1999). The rufous-sided towhee is also omnivorous, consuming both seeds and invertebrates (Greenlaw, 2015). As a result, relatively elevated $\mathrm{Pb}$ concentrations in northern cardinal and rufous-sided towhee would be expected compared to a granivore. However, high $\mathrm{Pb}$ concentrations were measured in the predominantly granivorous mourning dove (Mirarchi, 1993). Because the doves predominantly forage on the ground for seeds, incidental ingestion of $\mathrm{Pb}$-contaminated soil is possibly resulting in elevated $\mathrm{Pb}$ body burdens. Incidental soil ingestion is also possible for the northern cardinal and rufous-side towhee because they also forage on the ground. The brown thrasher largely consumes invertebrates and forages for them on the ground by probing the soils and leaf litter with its bill (Bent 1948). This foraging habit could lead to greater incidental soil ingestion rates relative to the other species, which may be the reason $\mathrm{Pb}$ concentrations in their feathers and blood are relatively high and $\delta$-ALAD activity is relatively low. As a result, greater risk would be estimated for birds that forage on the ground for invertebrates.

Elevated risk likelihood was estimated for Tyndall AFB relative to SJB. The highest likelihood was for the Carolina wren (34.0 percent), whereas the lowest risk was for the mourning dove ( 25.9 percent). As was the case for risk estimates for birds at Beale AFB, removal of the assumption of incidental soil ingestion reveals its considerable significance to the risk estimation. Dietary preference also had a significant effect on the risk estimation. Risk was lowest for the predominantly granivorous mourning dove and highest for the largely invertivorous wren. Although lower risk likelihood was estimated for birds at SJB relative to the AFB, the likelihood of approximately 5 percent for Category 1 effects is ironic given the overall low $\mathrm{Pb}$ concentrations in the dietary items and soils. Two factors are likely responsible for the greater than expected risk. First, the $\mathrm{Pb}$ concentration in one of the pitfall trap samples was $459 \mathrm{mg} / \mathrm{kg} \mathrm{dw}$, which was the highest measured at any of the locations (SJB, Tyndall AFB, Beale AFB, and the Beale reference area). Second, the assumption for the distribution (log normal) of possible contamination levels in invertebrates at $\mathrm{SJB}$ along with the high $\mathrm{Pb}$ concentration in the one pitfall trap sample results in a skew towards greater $\mathrm{Pb}$ concentrations than those measured. As a result, a small proportion of the risk quotients estimated during Monte Carlo sampling of the distribution exceeded one.

In summary, $\mathrm{Pb}$ contamination of soils at the AFB is sufficient to raise $\mathrm{Pb}$ exposure for birds to the point that they might be adversely affected. This was supported by depressed $\delta$-ALAD activity and predicted by the probabilistic risk assessment. However, risk is not likely to be uniform for all bird species as it will depend upon the dietary preferences and foraging behavior of the species. 


\section{References Cited}

Anders, E., Dietz, D.D., Bagnell, Jr., C.R., Gaynor, J., Krigman, M.R., Ross, D.W., Leander, J.D., and Mushak, P., 1982, Morphological, pharmacokinetic, and hematological studies of lead-exposed pigeons: Environmental Research, v. 28 , p. 344-363, accessed January 11, 2018, at https://ac.els-cdn.com/0013935182901347/1-s2.00013935182901347-main.pdf? tid=d5c39729-e4f0-49bf8db2-5376dc7ac5fd\&acdnat $=1531915920 \_9 a 3 d 961562621$ $6879 \mathrm{df} 5 \mathrm{c} 731 \mathrm{~d} 155 \mathrm{c} 6 \mathrm{a} 0$ ?

Bargar, T.A., 2019, Assessment of bird exposure to lead at Tyndall and Beale Air Force Bases, 2016-17: U.S. Geological Survey data release, https://doi.org/10.5066/ P92YXMQ2.

Bauerová, P., Vinklerová, J., Hranick, J., Corba, V., Vojtek, L., Svobodova, J., and Vinkler, M., 2017, Associations of urban environmental pollution with health-related physiological traits in a free-living bird species: Science of the Total Environment, v. 601-602, p. 1556-1565, accessed May 10, 2018, at http://dx.doi.org/10.1016/j.scitotenv.2017.05.276.

Bent, A.C., 1948, Life histories of North American nuthatches, wrens, thrashers, and their allies: Smithsonian Institution United States National Museum Bulletin no. 195, 461 p., accessed May 2018, at https://doi.org/10.5479/ si.03629236.195.1.

Berlin, A., and Schaller, K.H., 1974, European standardized method for the determination of delta-aminolevulinic acid dehydratase activity in blood: Clinical Chemistry and Clinical Biochemistry, v. 12, p. 389-390, accessed September 26, 2018, at DOI: $10.1515 / \mathrm{cclm} .1974 .12 .8 .389$.

Beyer, W.N., Chen, Y., Henry, P., May, T., Mosby, D., Rattner, B.A., Shearn-Bochsler, V.I., Sprague, D., and Weber, J., 2014, Toxicity of Pb-contaminated soil to Japanese quail (Coturnix japonica) and the use of the blood-dietary $\mathrm{Pb}$ slope in risk assessment: Integrated Environmental Assessment and Management, v. 10, p. 22-29, accessed August 10, 2015, at https://doi.org/10.1002/ieam.1453.

Beyer, W.N., Conner, E.E., and Gerould, S., 1994, Estimates of soil ingestion by wildlife: Journal of Wildlife Management, v. 58, p. 375-382, accessed May 17, 2018, at https:// www.jstor.org/stable/3809405.

Beyer, W.N., Spann, J.W., Sileo, L., and Franson, J.C., 1988, Lead poisoning in six captive avian species: Archives of Environmental Contamination and Toxicology, v. 17, p. 121-130, accessed January 11, 2018, at https://link.springer. com/content/pdf/10.1007/BF01055162.pdf.
Buekers, J., Redeker, E.S., and Smolders, E., 2009, Lead toxicity to wildlife: derivation of a critical blood concentration for wildlife monitoring based on literature data: Science of the Total Environment, v. 407, p. 3431-3438, accessed August 10, 2015, at https://doi.org/10.1016/j.scitotenv.2009.01.044.

Burger, J., and Gochfeld, M., 2000, Metal levels in feathers of 12 species of seabirds from Midway Atoll in the northern Pacific Ocean: Science of the Total Environment, v. 257, p. 37-52, accessed March 30, 2016, at https://doi. org/10.1016/S0048-9697(00)00496-4.

Cooper, Z., Bringolf, R., Cooper, R., Loftis, K., Bryan, A.L., and Martin, J.A., 2017, Heavy metal bioaccumulation in two passerines with differing migration strategies: Science of the Total Environment, v. 592, p. 25-32, accessed May 10, 2018, at https://doi.org/10.1016/j.scitotenv.2017.03.055.

Dieter, M.P., and Finley, M.T., 1979, $\Delta$-aminolevulinic acid dehydratase enzyme activity in blood, brain, and liver of lead-dosed ducks: Environmental Research, v. 19, p. 127-135, accessed January 11, 2018, at https://doi. org/10.1016/0013-9351(79)90041-0.

Eisler, R., 1988, Lead hazards to fish, wildlife, and invertebrates: a synoptic review: U.S. Fish and Wildlife Service Biological Report 85 (1.14), p. 94, accessed March 23, 2016, at https://pubs.er.usgs.gov/publication/5200021.

Franson, J.C., and Pain, D., 2011, Lead in birds, chap. 16 of Beyer, W.N. and Meador, J., eds., Environmental contaminants in biota: Interpreting tissue concentrations ( $2 \mathrm{~d}$ ed.): Boca Raton, Fla., CRC Press, p. 563-593.

Goede, A.A., and de Bruin, M., 1984, The use of bird feather parts as a monitor for metal pollution: Environmental Pollution Series B, Chemical and Physical, v. 8, p. 281-298, accessed March 31, 2016, at https://doi.org/10.1016/0143148X(84)90028-4.

Golden, N.H., Rattner, B.A., Cohen, J.B., Hoffman, D.J., Russek-Cohen, Estelle, and Ottinger, M.A., 2003, Lead accumulation in feathers of nestling black-crowned night herons (Nycticorax nycticorax) experimentally treated in the field: Environmental Toxicology and Chemistry, v. 22, p. 1517-1524, accessed at June 18, 2018, at https://doi. org/10.1002/etc.5620220713.

Goyer, R.A., 1986, Toxic effects of metals, chap. 19, p. 598-606, in Klaassen, C.D., Amdur, M.W. and Doull, J., eds., Casarett and Doull's Toxicology, The Basic Science of Poisons, (3d ed.), New York, MacMillan Publishing Company, $974 \mathrm{p}$. 
Greenlaw, J.S., 2015, Eastern Towhee (Pipilo erythrophthalmus), vers. 2.0, in Rodewald, P.G., ed., The Birds of North America: Ithaca, N.Y., Cornell Lab of Ornithology [not paged], accessed June 20, 2018, at https://birdsna.org/ Species-Account/bna/species/norcar/foodhabits.

Hagger, J.A., Jones, M.B., Leonard, D.R.P., Owen, R., and Galloway, T.S., 2006, Biomarkers and integrated environmental risk assessment - are there more questions than answers: Integrated Environmental Assessment and Management, v. 2, p. 312-329, accessed June 27, 2018, at https://doi.org/10.1002/ieam.5630020403.

Halkin, S.L., and Linville, S.U., 1999, Northern cardinal (Cardinalis cardinalis), vers. 2.0, in Poole, A.F., and Gill, F.B., eds., Ithaca, N.Y., Cornell Lab of Ornithology, [not paged], accessed June 20, 2018, at https://birdsna.org/SpeciesAccount/bna/species/norcar/foodhabits.

Hernberg, S., M.D., Nikkanen, J., Mellin, G., and Lilius, H., 1970, $\delta$-Aminolevunlinic acid dehydrase as a measure of lead exposure: Archives of Environmental Health: An International Journal, v. 21, p. 140-145, accessed February 10, 2015, at https://doi.org/10.1080/00039896.1970.10667211.

Hoffman, D.J., Heinz, G.H., Sileo, L., Audet, D.J., Campbell, J.K., and LeCaptain, L.J., 2000, Developmental toxicity of lead-contaminated sediment to mallard ducklings: Archives of Environmental Contamination and Toxicology, v. 39, p. 221-232, accessed January 11, 2018, at https://link. springer.com/content/pdf/10.1007/s002440010099.pdf.

Hough, E., and Grinnell, G.B., 1894, Lead-poisoned ducks: Forest Stream, v. 42, p. 117-118, accessed January 12,2018 , at https://www.biodiversitylibrary.org/ item/176808\#page/128/mode/1up.

Johnson, M.S., Wickwire, W.T., Quinn Jr., M.J., Ziolkowski, Jr., D.J., Burmistrov, D., Menzie, C.A., Geraghty, C., Minnich, M., and Parson, P.F., 2007, Are songbirds at risk from lead at small arms ranges? An application of the spatially explicit exposure model: Environmental Toxicology and Chemistry, v. 26, p. 2215-2225, accessed May 14, 2018, at https://doi.org/10.1897/07-068R.1.

Kerr, R., Holloday, S., Jarrett, T., Selcer, B., Meldrum, B., Williams, S., Tannenbaum, L., Holladay, J., Williams, J., and Gogal, R., 2011, Oral lead bullet fragment exposure in northern bobwhite (Colinus virginianus): Archives of Environmental Contamination and Toxicology, v. 61, p. 668-676, accessed July 30, 2015, at https://doi.org/10.1007/ s00244-011-9654-2.

Kramer, J.L., and Redig, R.T., 1997, Sixteen years of lead poisoning in eagles, 1980-95: and epizootiologic view: Journal of Raptor Research, v. 31, p. 327-332, accessed March 22, 2016, at https://pdfs.semanticscholar.org/7b1f/20e17042b21 4e6a091279e9a572d2792e975.pdf.
Kristensen, L.J., 2015, Quantification of atmospheric lead emissions from 70 years of leaded petrol consumption in Australia: Atmospheric Environment, v. 111, p. 195-201, accessed January 12, 2018, at https://doi.org/10.1016/j. atmosenv.2015.04.012.

Laidlaw, M.A.S., Mohmmad, S.M., Gulson, B.L., Taylor, M.P., Kirstensen, L.J., and Birch, G., 2017, Estimates of potential childhood lead exposure from contaminated soil using the US EPA IEUBK model in Sydney, Australia: Environmental Research, v. 156, p. 781-790, accessed January 12, 2018, at https://doi.org/10.1016/j.envres.2017.04.040.

Lovering, T.G., 1976, Lead in the environment-summary, chap. 1 of Lovering, T.G., ed., Geological Survey Professional Paper 957: U.S. Geological Survey, p. 1-4, accessed January 11, 2018, at https://pubs.usgs.gov/pp/0957/report. pdf.

Mirarchi, R.E., 1993, Energetics, metabolism and reproductive physiology, chap. 9 of Basket, T.S., Sayre, M.W., Tomlinson, R.E., and Mirarchi, R.E., eds., Ecology and management of the mourning dove: Harrisburg, Pa., Stackpole Books, p. 143-160.

Moorman, C.E., Bowen, L.T., Kilgo, J.C., Sorenson, C.E., Hanula, J.L., Horn, S., and Ulyshen, M.D., 2007, Seasonal diets of insectivorous birds using canopy gaps in a bottomland forest: Journal of Field Ornithology, v. 78, p. 11-20, accessed June 27, 2018, at https://www.jstor.org/ stable/27715175.

Nagy, K., 1987, Field metabolic rate and food requirement scaling in mammals and birds: Ecological Monographs, v. 57, p. 111-128, accessed September 10, 2018 at DOI: $10.2307 / 1942620$.

Pain, D.J., 1989, Haematological parameters as predictors of blood lead and indicators of lead poisoning in the black duck (Anas rubripes): Environmental Pollution, v. 60 , p. 67-81, accessed July 28,2015 , https://doi. org/10.1016/0269-7491(89)90221-2.

Pavlowsky, R.T., Lecce, S.A., Owen, M.R., and Martin, D.J., 2017, Legacy sediment, lead, and zinc storage in channel and flood plain deposits of the Big River, Old Lead Belt Mining District, Missouri, USA: Geomorphology, v. 299, p. 54-75, accessed January 12, 2018, at https://doi. org/10.1016/j.geomorph.2017.08.042.

Sakai, T., Yanagihara, S., Kunugi, Y., and Ushio, K., 1983, Mechanisms of ALA-D inhibition of lead and of its restoration by zinc and dithiothreitol: British Journal of Industrial Medicine, v. 40, p. 61-66, accessed January 22, 2016, at https://www.jstor.org/stable/27723674. 
Schreiber, W.E., Azim Jamani, R.T., and Pudek, M.R., 1989, Screening tests for porphobilinogen are insensitive, the problem and its solution: American Journal of Clinical Pathology, v. 92, p. 644-649, https://doi.org/10.1093/ ajcp/92.5.644.

Schulz, J.H., Millspaugh, J.J., Bermudez, A.J., Gao, X., Bonnot, T.W., Britt, L.G., and Paine, M., 2006, Acute lead toxicosis in mourning doves: Journal of Wildlife Management, v. 70, p. 413-421, accessed July 28, 2015, at https://doi. org/10.2193/0022-541X(2006)70[413:ALTIMD]2.0.CO;2.

Tsipoura, N., Burger, J., Newhouse, M., Jeitner, C., Gochfeld, M., and Mizrahi, D., 2011, Lead, mercury, cadmium, chromium, and arsenic levels in eggs, feathers, and tissues of Canada geese of the New Jersey Meadowlands: Environmental Research, v. 111, p. 775-784, accessed July 28, 2015, at https://doi.org/10.1016/j.envres.2011.05.013.

U.S. Environmental Protection Agency (EPA), 1993, Wildlife exposure factors handbook, Volume 1, EPA/600/R-93/187: Washington, D.C., U.S. Environmental Protection Agency, 572 p. [Also available at https://nepis.epa.gov/Exe/ZyNET. exe/P100GJ60.TXT?ZyActionD=ZyDocument\&Client=EP A\&Index $=1991+$ Thru $+1994 \&$ Docs $=\&$ Query $=\&$ Time $=\&$ En dTime $=\&$ SearchMethod $=1 \&$ TocRestrict $=$ n $\&$ Toc $=\&$ TocEnt ry $=\& Q$ Field $=\& Q$ FieldYear $=\& Q$ FieldMonth $=\& Q$ FieldDay $=\&$ IntQFieldOp $=0 \&$ ExtQFieldOp $=0 \&$ XmlQuery $=\&$ File $=\mathrm{D}$ $\% 3 \mathrm{~A} \% 5$ Czyfiles\%5CIndex\%20Data\%5C91thru94\%5CTxt $\% 5 \mathrm{C} 00000029 \% 5 \mathrm{CP} 100 \mathrm{GJ} 60 . \mathrm{txt} \&$ User=ANONYMOUS\& Password=anonymous $\&$ SortMethod $=\mathrm{h} \% 7 \mathrm{C}-\&$ MaximumDo cuments $=1 \&$ FuzzyDegree $=0 \&$ ImageQuality $=\mathrm{r} 75 \mathrm{~g} 8 / \mathrm{r} 75 \mathrm{~g} 8 /$ x150y150g16/i425\&Display $=$ hpfr\&DefSeekPage $=x \&$ Sear chBack=ZyActionL\&Back=ZyActionS\&BackDesc $=$ Resu 1ts $\% 20$ page $\&$ MaximumPages $=1 \& Z y$ Entry $=1 \&$ SeekPage $=\mathrm{x}$ \&ZyPURL.]

U.S. Environmental Protection Agency (EPA), 2005, Ecological soil screening levels for lead- Interim final, Office of Solid Waste and Emergency Response Directive 9285.7-70: Washington, D.C., U.S. Environmental Protection Agency, 242 p., accessed January 16, 2007, https://www.epa.gov/ sites/production/files/2015-09/documents/eco-ssl_lead.pdf.

Vallverdu-Coll, N., Lopez-Anita, A., Martinez-Haro, M., Ortiz-Santaliestra, M.E., and Mateo, R., 2015, Altered immune response in mallard ducklings exposed to lead through maternal transfer in the wild: Environmental Pollution, v. 205, p. 350-356, accessed March 21, 2016, at https://doi.org/10.1016/j.envpol.2015.06.014. 
For additional information, contact::

Director, Wetland and Aquatic Research Center U.S. Geological Survey

7920 NW 71st Street

Gainesville, FL 32653

or visit our website at: https://www.usgs.gov/warc

Publishing support provided by the

West Trenton Publishing Service Center 

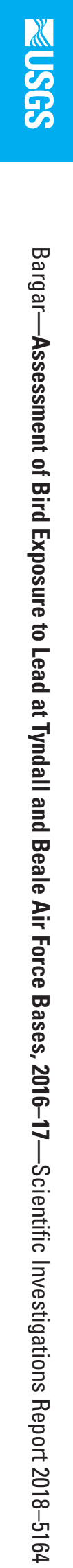